\title{
STROKOVNE ANALIZE V PROSTORSKEM PLANIRANJU
}

\author{
Andrej Černe \\ Oddelek za geografijo Filozofske fakultete Univerze v Ljubljani, \\ Aškerčeva cesta 2, SI - 1000, Ljubljana, Slovenija \\ e-pošta: andrej.cerne@guest.arnes.si \\ Izvirni znanstveni članek \\ COBISS 1.01
}

\section{Izvleček}

Analiza prispeva $\mathrm{k}$ uresničevanju treh temeljnih splošnih namenov prostorskega planiranja: je podlaga procesu nastajanja politik, konceptov in strategij, daje temeljne informacije prebivalcem, lastnikom zemljišč, investitorjem in planerjem ter pomaga pri izvajanju prostorskih politik, strategij, planov, programov in projektov. Analiza je v planiranju na splošno namenjena:

- $\quad$ razumevanju sedanjih razmer in pogojev, znotraj katerih sprejemamo planske odločitve;

- opredeljevanju prioritetnih vprašanj in njihovemu reševanju;

- oblikovanju splošnih načel za nadaljnja razvojna prizadevanja.

Ključne besede: prostorsko planiranje, prostorski koncepti, analiza prostora

\section{PROFESSIONAL ANALYSIS IN SPATIAL PLANNING}

\begin{abstract}
Spatial analysis contributes to accomplishment of the three basic aims of spatial planning: it is basic element for setting spatial policies, concepts and strategies, gives basic information to inhabitants, land owners, investors, planners and helps in performing spatial policies, strategies, plans, programmes and projects. Analysis in planning are generally devoted to:

- understand current circumstances and emerging conditions within planning decisions;

- determine priorities of open questions and their solutions;

- formulate general principles for further development.
\end{abstract}

Key words: spatial planning, spatial concepts, spatial analysis 


\section{PRISTOP}

Strokovne analize so del integracijskega procesa priprave planov in obsegajo metode opisa, razlag, vrednotenja, predlogov, implementacij in monitoringa. K prostorskemu planiranju prispevajo na več načinov. Prvič, jasna slika o sedanjem stanju, razmerah in prihodnjih težnjah pomaga pri opredeljevanju vprašanj, ciljev in njihovih prioritet. Drugič, dobra analiza sedanjih in prihodnjih razmer prispeva $\mathrm{k}$ iskanju dobrih rešitev za razvojne probleme. Tretjič, dobra strokovna analitična podlaga pomaga pri utemeljevanju in obrazložitvi ter izvajanju politik, strategij in planov. Strokovne analize so podlaga procesu nastajanja politik, konceptov in strategij, dajejo temeljne informacije prebivalcem, lastnikom zemljišč, investitorjem in planerjem ter pomagajo pri izvajanju prostorskih politik, strategij, planov, programov in projektov. Strokovne analize so na splošno namenjene:

- razumevanju sedanjih razmer in pogojev, znotraj katerih sprejemamo odločitve;

- opredeljevanju prioritetnih vprašanj in njihovemu reševanju;

- oblikovanju splošnih načel za nadaljnja razvojna prizadevanja.

Strateški pristop v planiranju je osredotočen v cilje plana in različne možne koncepte za njihovo doseganje. Poudarek je na iskanju možnih posledic alternativnih konceptov za prihodnji prostorski razvoj. Zato sledi planiranje na področju strokovnih analiz trem stopnjam:

- opisni stopnji celotnega območja, vključno z opredeljevanjem prostorskih problemov;

- analitični stopnji raziskovanja temeljnih razvojnih teženj in njihovih predvidenih posledic;

- stopnji sintetiziranja spoznanj v prostorske koncepte kot podlage za zasnovo prostorskega razvoja.

Proces opredeljevanja in nastajanja prostorskih dokumentov je na splošno organiziran na različnih stopnjah, od priprave splošne politike in strategij do planov, programov in projektov ter posebnih meril. Proces poteka od usmeritev k načinom usmerjanja, od dolgoročnega h kratkoročnemu oziroma od splošnega k posebnemu planiranju.

Stopnje in različne naloge pri pripravi prostorskih dokumentov so vsebinsko in postopkovno povezane in soodvisne. Priprava prostorskih dokumentov je proces, ki poskuša združevati strokovno analizo z različnimi oblikami planov. Čeprav je strokovna analiza izrednega pomena pri samem procesu priprave prostorskega dokumenta in pravzaprav nosi večino razlag za nadaljnje postopke, pa ni iskanje poti za reševanje prostorskih problemov. To je namreč naloga samega plana, in sicer najpogosteje v obliki preskoka od strokovnih analiz na področje sintez, s katerimi se predlaga rešitve.

$\mathrm{V}$ vseh omenjenih stopnjah priprave prostorskih dokumentov imamo hkrati opravka $\mathrm{z}$ naslednjimi temeljnimi vsebinami: $\mathrm{z}$ analizo stvarnih razmer, $\mathrm{z}$ vizijo, kakšno prostorsko strukturo naj bi zasnovali, in s podrobnejšim opisom načinov za njeno doseganje. Prostorski dokumenti morajo imeti torej vsaj tri sestavne dele: dejstva, cilje in priporočila.

Analiza je najpogosteje umeščena v naslednje temeljne vsebinske okvirje:

- analiza stanja in teženj, ki opisuje obstoječe in prihodnje prostorske razmere in pogoje; 
- ocena stanja, vključno z relativnim pomenom prostorskih problemov ali stopnjo doseganja ciljev, ter dejavniki, ki povzročajo prostorske probleme;

- $\quad$ vrednote, ki opredeljujejo cilje, probleme ali vprašanja in prioritete med njimi;

- politika, ki opisuje načela za usmerjanje prostorskega planiranja, reševanje problemov in usmerjanje razvoja.

Čeprav je sama analiza velikokrat opredeljena pred cilji, potekajo omenjene naloge vedno sočasno. Analiza opisuje prostorske razmere zaradi opredeljevanja oziroma spoznavanja dejstev o prostoru, ključnih dejavnikov, pojavov in procesov, teženj in prihodnjih pogojev, ki bodo verjetno vplivali na prostorske razmere. Analiza je najpogosteje podana v obliki numeričnih podatkov, ki predstavljajo določene vrednosti, v obliki natančnih spoznanj o vsem, kar se je zgodilo (kronologija, razvoj, vzrok in posledica), v obliki nekaterih zanimivosti, značilnosti in lastnosti posameznega pojava in procesa ali v obliki opisa dinamičnih elementov razvoja oziroma rasti in sprememb. Obrazložitve in utemeljitve niso vedno podprte z veljavnimi in prepričljivimi argumenti ter dokazi. Pogosto so omejene samo na stvari, upoštevani pa so zgolj argumenti, ki govorijo v prid teze. Številna dejstva, njihova veljavnost in pomembnost zahtevajo podrobnejšo analizo in interpretacijo oziroma razlago.

Analiza se nanaša na relevantne razmere in pogoje, zato lahko seveda zadeva številne in različne oziroma vse mogoče analize, in sicer na vseh prostorskih ravneh: iskanje dejstev o prostoru ali spoznanj o dejstvih, analizo problemov, pretresanje obstoječih razmer, oceno okolja, analizo ustreznih pogojev ali informacijsko podlago, analizo rabe zemljišč itd. Zato je treba določiti področja in območja analiz. Vedeti moramo, kakšen pojav moramo proučevati, katera vprašanja si moramo zastavljati in kakšna filozofska stališča morajo usmerjati naše raziskave. Analiza kot taka potrebuje omejitve in samo konceptualna definicija jih lahko tudi omogoča. Merila za opredelitev področja in območja prostorskih analiz se nanašajo predvsem na relevantnost analiziranih vsebin. Vsebine prostorskih analiz so relevantne glede na:

- cilje, to pomeni, da se nanašajo na opazovanja, predpostavke, sklepe in dedukcije o problemih, potrebah in ciljnih pogojih;

- vzročne dejavnike, ki vplivajo na probleme, potrebe in ciljne pogoje;

- izvedljivost ali učinkovitost potencialnih rešitev (Černe, Kušar, 2002).

\section{PREDMET ANALIZE PROSTORSKEGA PLANIRANJA}

Planiranje ima geografsko, časovno, funkcijsko, in institucionalno razsežnost. Časovna izhaja iz usmerjenosti planiranja v prihodnost. Iz preteklosti izbira elemente in dejavnike, ki so temeljnega pomena za analiziranje obstoječih pogojev nadaljnjega razvoja oziroma za opredeljevanje možnih in zaželenih sprememb ter poti do njih (Friedmann, 1987). Prostorsko planiranje se ukvarja z vprašanji prostorskega nameščanja razvoja, ne z njegovim splošnim preprečevanjem, vendar ob pomembnem spoznanju, da ima prostor omejene sposobnosti za nameščanje razvoja in rasti. Bilo bi zelo nevarno, če bi se prostorsko planiranje ločilo oziroma odmaknilo od razvojnih interesov. 
Osrednji predmet prostorskega planiranja (tu imamo v mislih predmet planiranja oziroma, bolje, tisto, kar se planira) je izrazito prostorski. Materialni predmet planiranja je prostor kot fizična stvarnost, njegov formalni predmet pa odločanje o »posegih v prostor«. Končni namen planiranja je seveda vplivanje na spremembe materialnega predmeta - prostora. Besedo prostor uporabljamo v njenem najširšem pomenu, saj ni omejena samo na trodimenzionalno geometrijo, marveč se nanaša tudi na gospodarski ali psihološki in zaznavni prostor. Prostor je najpogosteje izražen v obliki zemeljskega površja. Ne pomeni prostora v smislu zunanjega prostora (vesolja), niti prostora v smislu urejenih stvari v vrsti. Prostor lahko merimo v smislu njegove dolžine (razdalja) ali površine (obseg). Lahko ga merimo v znanih geometričnih, ekonomskih ali drugih enotah (npr. kot psihološke enote v smislu domačnosti ali strahu). Razdalja ima pri tem dvojni pomen. Prvič, ločuje predmete v prostoru, v ravnini, v kateri obstajajo, in drugič, ločuje opazovalca od predmetov v prostoru. Razdalja v pravem pomenu besede se nanaša na kartografijo, morfologijo in lokacijske analize. Druga razdalja se nanaša na vertikalni prostor in ideje o merilu. Če gledamo predmete od blizu, lahko vidimo podrobnosti, če jih gledamo od daleč, vidimo le grobe obrise. Srečamo se s sočasnim obstojem splošnih značilnosti prostora in posameznih značilnosti krajev, ki so vidiki istega oziroma od človeka preoblikovanega zemeljskega površja kot celote.

Pri analizi nas zanima, kaj se dogaja s prostorom. Vedeti hočemo, kje je, kakšen je, kako je nastal in kakšne posledice prinaša. Ne gre torej zgolj za vprašanja, kje in kako je prostor razporejen, marveč predvsem, zakaj je razporejen tako in ne drugače. Analiza je usmerjena predvsem v spoznavanje pojavov in procesov, ki so privedli do določene prostorske strukture, in njenih posledic. Kaj se dogaja s pokrajinami, regijami, urbanimi območji in različnimi kraji, ne moremo razumeti brez razmerij, ki vplivajo na nastajanje teh enot, kakor tudi ne moremo razumeti teh razmerij neodvisno od tega, kar se dogaja $\mathrm{v}$ določenih območjih. Za prostorski sistem je značilno, da nikoli nima stalne stabilnosti in trajnosti oblik, funkcij in strukture. Prostorske enote so nekako utelešene v stvarnih procesih, katerih lastnosti ne moremo proučevati neodvisno od "prostorske-časovnosti«, ki jo vsebujejo. Vprašanja, ki si jih zastavljamo o lokacijah, gibanju prebivalstva, krajih, naseljih, obravnavajo dogodke v primarnem, fizičnem prostoru. Vsi pojavi tvorijo določeno prostorsko strukturo, vzroki oziroma procesi, ki so privedli do tega, pa seveda niso vedno in edino prostorski. Zato tudi ne moremo pričakovati, da bomo našli odgovore na vse prostorske probleme samo v prostorskem smislu.

Prostorska znanost je osredotočena na opredeljevanje vloge prostora kot temeljnega dejavnika, ki vpliva tako na organizacijo družbe kot na njeno delovanje ter vedenje njenih posameznih članov. Izoblikovala se je med kvantitativno revolucijo in je bila najpogosteje tesno povezana s pozitivistično filozofijo (lokacijske analize).

Prostorske analize so osredotočene na tri medsebojno povezane vsebine: prostorsko organizacijo, prostorsko-časovne procese in napovedovanje prihodnjega prostorskega razvoja. Prostorska organizacija nam pomeni prostorske značilnosti razporeditve pojavov in procesov v pokrajini: lego, položaj (absolutno in relativno lokacijo), zunanjo podobo naselij, mest, prometnic, industrijskih obratov itd. Prostorski analitiki so praviloma opredeljevali te pojave v obliki točk, linij in območij (arealov) ter pri tem poudarjali predvsem njihove 
geometrične oziroma morfološke značilnosti. Analize prostorskega vzorca, prostorska avtokorelacija in prostorska difuzija so izražene v Evklidovi geometriji. Prostorska razporeditev naselij upošteva naselja kot točke v prostoru, kar pomeni, da zanemarja njihovo velikost in funkcije. Taka obravnava predstavlja naselja zgolj v obliki centroida. To pa vendarle omogoča analizo omrežij in raziskave na področju oblik in prostorskih značilnosti razporeditve naselij. Morfometrične analize torej lahko vodijo k določenim tipom prediktivnih in simulacijskih modelov. Številne tehnike za opredeljevanje prostorskega vzorca in prostorskega časovnega napovedovanja so omogočile spoznanja o nekaterih pravilnostih razporeditve pojavov in procesov v prostoru. S poznavanjem geometričnih pravil teorije o centralnih naseljih, gostote prebivalstva in velikosti ter lokacije naselij je mogoče opredeliti tudi ostala naselja v omrežju. V ekstremnih primerih to pomeni, da je analiza osredotočena na prostorsko razporeditev pojavov v pokrajini, ne pa na same pojave.

Prostorske analize so tesno povezane s pozitivistično razlago, saj gre najpogosteje za formalne modele prostorske organizacije ter upoštevanje predpostavk in stvarnega poznavanja prostorske organizacije in prostorsko-časovnih procesov. Humanisti in strukturalisti imajo odklonilen odnos do geometrične konfiguracije človekovih dejavnosti. Humanisti zato, ker prostorske analize negirajo človekov svet izkušenj in pomen okolja za človeka. Strukturalisti pa so nezaupljivi do prostorskih analiz zato, ker opisujejo samo navidezno ali površinsko zgradbo, ne pa razmerij, ki so bistvena za družbo kot celoto.

Prostorske planerje najpogosteje zanima prostorska razsežnost gospodarstva in družbe kot celote. Še prav posebej se posvečajo prostorskim razmerjem med socialnimi in gospodarskimi dejavnostmi, oziroma strukturi prostora, kjer te dejavnosti potekajo. Planerji morajo poznati velikost in lokacijo gospodarskega prostora ter njegove funkcije oziroma prostorska razmerja med dejavnostmi. Ne glede na to, kako je lahko stvarni prostor popačen zaradi ekonomskih ali psiholoških dejavnikov, mora biti osrednji predmet zanimanja prostorskih planerjev proučevanje medsebojnih prostorskih razmerij v stvarnem (geografskem) prostoru. S prostorskega vidika je temeljnega pomena, da ima razvoj prostorsko komponento oziroma razsežnost. Za proizvodnjo in potrošnjo je značilna prostorska dispariteta, za premagovanje razdalj v prostoru pa potrebujemo čas, energijo in denar. Vse dejavnosti so takšni ali drugačni porabniki prostora. Prostorski vidik je danes razmeroma zelo drugačen od prvotnega razumevanja tega pojma, čeprav je bil koncept prostora oziroma prostorski koncept vedno upoštevan. Prostorski koncepti se nanašajo namreč na prostorsko razporeditev, prostorsko integracijo, medsebojne prostorske vplive in prostorske procese. Vse to pa se nanaša na ekosistem, katerega pomemben sestavni del je človek.

Analiza mora upoštevati različnosti prostora, družbe, ekosistemov in kultur. Gre za pluralnost različnih prostorov in ne za en vseobsegajoči super prostor. Pokrajine in regije so sistem urejene prostorske različnosti, kjer je prostor individualiziran kot enkraten prostor na podlagi vzajemnih razmerij in medsebojne povezanosti vseh njihovih sestavnih delov. Gre za opredeljevanje prostora kot razmerja med lastnostmi in ne kot razmerja med substancami. Pokrajine in regije so nastale $\mathrm{z}$ različnimi medsebojno delujočimi procesi, ki so vplivali na njihov nastanek na različnih prostorskih ravneh in v različnih obdobjih. Ne gre torej za pokrajine, ki so dane, po naravi ali zgodovini, za različne prostorske enote kot stvari, marveč za območja, ki so nestabilni proizvod različnih pojavov in procesov, ki so nastajali na 
različnih prostorskih ravneh in $\mathrm{v}$ različnih obdobjih. Zato jih moramo obravnavati kot individualne kraje, ne pa kot abstraktne prostore. Pokrajine so notranje raznolike dialektične in dinamične oblike relativne »trajnosti«, podvržene neprestanim spremembam znotraj splošne prostorske in časovne dinamike razvoja. Prostorska struktura pokrajin ni stabilna, ni večno stanje razmerij. Po pravilu se pokrajine in regije spreminjajo, slednje včasih zelo hitro.

Analiza je namenjena odkrivanju, spoznavanju in razumevanju tistega, kar obstaja. Z njo odkrivamo, spoznavamo in razumevamo različne pomene, ki so potencialno prisotni $\mathrm{v}$ pokrajinah in regijah. Te so nekakšne prostorske identitete, bolj ali manj opredeljene s prepletanjem izjemnosti, posebnosti in univerzalnosti. Če je prostor resnični temeljni vidik človekovega bivanja, če je res vir varnosti in identitete za posameznika in skupnost, potem je treba ohranjati in razvijati njegove različne pomene. Prostora ne moremo obravnavati kot nediferencirano prostorsko enoto, marveč kot nekaj, kar je raznovrstno in pogosto v notranjih protislovjih. Pri tem pa ne gre za prostorske razlike same po sebi, marveč predvsem za njihove pomene. Razlike so bolj rezultat neenakomernega prostorskega in časovnega investiranja kapitala, delitve dela in segmentacije dejavnosti znotraj različnih pogojev in razmer. Seveda nikoli niso absolutna drugačnost, popolna odsotnost razmerij ali skupnih lastnosti. Podobnost kot merilo različnosti in drugačnosti zahteva prav tako pozornost kot ustvarjanje drugačnosti in različnosti. Nobene ne moremo opredeljevati brez druge. Odkrivanje podobnosti je odkrivanje lastnosti, ki so temeljnega pomena za oblikovanje zvez med navidezno različnimi območji in posameznimi lastnostmi. Znotraj tega konteksta se seveda nikoli ne moremo izogniti univerzalnosti, ki je zasnovana na dialektičnih razmerjih s posebnostmi. Merila univerzalnosti so vedno opredeljena tudi s posebnostmi. Univerzalnost pa mora biti zasnovana kot različnost ustvarjanja, ki poteka na zelo različnih prostorskih ravneh in $\mathrm{v}$ zelo različnih obdobjih (Černe, 1999).

$\mathrm{V}$ tem kontekstu je temeljnega pomena »kakovost prostora«, ki se nanaša na poskuse združevanja oziroma povezovanja družbenih vrednot s spremembami in stabilnostjo prostorske strukture. Kakovost prostora se spreminja, poleg tega se spreminja njegova relativna lokacija in končno se spreminja njegova geografska razsežnost. Spreminjanje strukture prostora, pojavov in procesov ter njihovih razmerij vpliva namreč tudi na spremembo relativnega položaja pokrajin in regij znotraj globalnega vzorca prostorskih razmerij. Številne in različne možne razsežnosti kakovosti prostora, ki se lahko izražajo v zelo različnih stopnjah, se po Lynchu (Lynch, 1981, str. 118-119) nanašajo na: vitalnost, jasnost zaznave, prilagodljivost, dostopnost, nadzor, učinkovitost in pravičnost:

- vitalnost je neke vrste podpora, ki jo prostor ponuja človekovim dejavnostim, biološkim potrebam in zmožnostim;

- jasnost zaznave krajev kot strukture v prostoru in času s strani prebivalstva in različna stopnja povezanosti prostorske strukture $\mathrm{z}$ vrednotami prebivalcev;

- prilagodljivost je skladnost prostora z opremljenostjo ter dejavnostjo prebivalcev;

- dostopnost je sposobnost doseganja prebivalcev, krajev, dejavnosti, virov, storitev, informacij itd;

- nadzor je nadzor prebivalcev nad rabo, dostopnostjo in spremembami prostora ter dejavnostmi; 
- učinkovitost je relativen strošek ustvarjanja in vzdrževanja kakovosti prostora za različne ravni vitalnosti, občutka, prilagodljivosti in nadzora;

- pravičnost je uravnoteženost $\mathrm{v}$ razporeditvi okoljskih koristi in stroškov med območji in prebivalci.

\section{METODOLOŠKA IZHODIŠČA}

Analiza temelji na različnih strokovnih razlagah oziroma pojasnjevanjih, torej na opredelitvi, opisu ali utemeljitvi prostorske stvarnosti. Je eden izmed načinov za doseganje strokovne razlage, neke vrste poskus logične analize oblik in procesov nastajanja prostora. Vse znanje, pridobljeno z uporabo znanstvenih metod proučevanja, se bolj ali manj nanaša na pretekle dogodke. Planerji seveda potrebujejo še védenje o prihodnjih dogodkih, zato se ukvarjajo tudi z vizijami, koncepti, napovedovanjem in projekcijami oziroma snovanjem prihodnosti glede na želje in razvojne možnosti. Analiza podaja »skrbno in teoretično organizirano spoznavne rezultate« ter druge oblike spoznavnih rezultatov s področja različnih strok o različnih elementih, pojavih in procesih prostorske strukture. Analizo pojmujemo kot urejeno sistematično in preverjeno spoznanje, ki je rezultat skrbnega in natančnega metodološkega raziskovanja in proučevanja prostorskega razvoja, torej sistematičnega iskanja dejstev, iz katerih lahko izoblikujemo določena načela. Rezultati analize so sinteza dejstev, torej sinteza starih in poznanih ter novih nepoznanih dejstev. Gre za metodo pojasnitev in upravičevanja trditev ali sistema trditev o prostorski stvarnosti. Analiza je torej namenjena logični koherentnosti strokovnih razlag ter doseganju natančnosti formulacij, trditev in hipotez. Zato je njen osnovni cilj sistematična in metodična pojasnitev prostorske stvarnosti, prostorskih razmer, pojavov, procesov ter ugotovljenih splošnih povezav med njimi, in sicer na podlagi trdnih načel razlag oziroma prepoznavnih metodičnih razlag prostorskih pojavov in procesov. Pri tem so temeljnega pomena »pravila znanja«, ki nam določajo način ravnanja, saj nam narekujejo, kako ravnati z opisi dejstev, da dosežemo pravilno pojasnitev (razlago, napoved) (Černe, Kušar, 2002).

Analiza se nanaša na strukturo, funkcijo in razvoj. Pri tem je struktura »vsota« elementov in povezav med njimi, funkcija se nanaša na »tokove«, ki tvorijo povezave, razvoj pa pomeni spremembo $\mathrm{v}$ strukturi in funkciji $\mathrm{v}$ določenem času. Najpreprostejša oblika razvoja je sprememba $\mathrm{v}$ velikosti, strukturi ali sistemu ( $\mathrm{v}$ velikosti ali kompleksnosti celotnega območja in njenih sestavnih elementov); morfogeneza je proces, s katerim postane prostorski sistem strukturno različen, diferenciacija pa je proces, $v$ katerem se človek in dejavnosti prilagajajo posebnim in enkratnim pogojem in funkcijam prostora. $\mathrm{V}$ temeljih nas zanimajo vprašanja, kako so pojavi in procesi razporejeni in urejeni na zemeljskem površju in kateri dejavniki so vodili $\mathrm{k}$ taki prostorski razporeditvi ter seveda kako to vpliva na spreminjanje funkcije in podobe posameznih območij.

Analiza nastaja na podlagi različnih znanstvenoraziskovalnih in obrobnih metod: normativnih in zgodovinskih ter različnih genetskih in komparativnih metod, metod pregleda in kompilacije, anketiranja itd. Spoznanja analiz so torej rezultat uporabe različnih metod in tehnik, nastalih na podlagi postopkov, ki so značilni za različne stroke, ter na podlagi me- 
tod, ki se zelo razlikujejo po posameznih znanstvenih strokah. Zato so tudi rezultati predhodnih analiz oblikovani različno: najpogosteje z razpravljanjem, velikokrat s pripovedovanjem in opisovanjem. Analize vsebujejo različne oblike oziroma stopnje razlag, od popolnih (deduktivnih) razlag, razlag posameznih dejstev ali posameznega statističnega dejstva, induktivno-statističnih (verjetnostnih) in funkcionalno-teleoloških, dispozicijskih ter genetskih razlag do nepopolnih (hevrističnih, okrajšanih in delnih, obrisov razlag ter analoških) razlag (Ule, 1992). Številne strokovne analize izhajajo iz znanstvenih raziskav, nekatere iz vsakdanjega vedenja in osebnih izkušenj, opazovanj ali raznih razprav in so torej posledica vsakdanjega vedenja ali izkustva, torej vedenj, verovanj, načinov razmišljanja in predstav. Pri strokovnih razlagah gre za trojno razmerje: za razmerje med teorijo, dejstvom in kontekstom razlage. Strokovne razlage vsebujejo vse oblike strokovnega odgovarjanja na vprašanja, zakaj, kako, čemu itd. Razumevanje je širši pojem od razlage, saj tu ne gre nujno za odgovore na vprašanja: kako, zakaj, čemu, marveč za to, da najdemo smisel oziroma pomen tega, kar skušamo razumeti. Vsako razlago za neko obliko razumevanja imamo za sistematično povezavo dognanega s splošnimi, objektivnimi zakonitostmi določenega področja pojavov. S tega vidika je poskus razlage nekaj bistveno relativnega, kajti razlaga je odgovor, ki se ga ocenjuje nasproti določenemu vprašanju, in zato vsebuje zahtevo po informaciji. Kontekst razlage odloča, katera informacija se zahteva pri odgovoru na vprašanje: zakaj je prišlo do določenega pojava ali procesa. Pri razlagi gre torej za že uporabljeno znanost. Z njo namreč želimo zadovoljiti določene potrebe (želje), ki so v nekem pragmatičnem in epistemskem kontekstu. Pri tem se moramo zavedati, da nobena stroka ne podaja pravih vzrokov pojavov, namreč dokončnih in nujnih vzrokov, saj nobena nima značaja edine resnice. Pri vseh razlagah gre za prikaz tega, kako je prostorska struktura nastala (na kakšen način in pod katerimi pogoji) in kako so stvari medsebojno povezane. Razlage so torej bežen opis in niso esencialne. Strokovne razlage imajo svojo mejo, saj dajejo razlage $\mathrm{v}$ smislu enotne teorije in končno razlago o končnih razlogih - navajanje dejstev. Strokovne trditve se dajo namreč načeloma logično ali empirično preveriti ali zavrniti in so seveda podvržene tudi kritiki. Pri strokovnih razlagah gre najpogosteje za pojasnjevanje posameznega ali splošnega dejstva, procesa, pojava, lahko pa tudi teženj, ocen o možnostih itd. Opis razlage pa mora biti logična posledica hipoteze razlage, ki mora imeti empirično vsebino, torej mora biti vsaj načeloma empirično preverljiva. Nomotetičen pristop pomeni predvsem opazovati in opisovati pravilnosti, kot na primer prostorsko organizacijo človekovih dejavnosti, in je hkrati podlaga teoriji, ki naj bi ponujala temelje za ločevanje pomembnih od nepomembnih dejstev oziroma za oblikovanje meril, na podlagi katerih lahko primerjamo enkratne razmere in jih tudi prepoznavamo. Cilj takega pristopa je izražen $\mathrm{v}$ obliki zasnove natančne generalizacije $\mathrm{s}$ točnimi kvantitativnimi opisi prostorske razporeditve, prostorske strukture in organizacije ter prostorskih razmerij. Natančno generalizacijo pa je moč zasnovati na podlagi treh temeljnih prostorskih konceptov: usmeritve (orientacija), razdalje in povezanosti (relativnega položaja). Deduktivno-zakonska pojasni-tev, pa tudi vsaka deduktivno-statistična pojasnitev (Ule, 1992), je pojasnitev preteklih dogodkov (dejstev) ali pa napoved prihodnjih dogodkov. Načeloma se lahko pojasnitve tolmačijo tudi kot napovedi in nasprotno. Gre za tezo o strukturni enakovrednosti »dobre 
razlage« in »dobre napovedi«. Dejanska razlaga mora prinesti neko novo znanje, novo informacijo o razloženem, povečati mora stopnjo prepričanja o razloženem. Utemeljitve so razlage, ki povezujejo spoznano z osnovnimi spoznanji na nekem področju prostorskega razvoja in s tem »zavržejo možne dvome« o spoznanem. Utemeljitve običajno pomembneje poglobijo naše znanje in/ali dopolnijo naša spoznanja.

Pri analizi poskušamo izbrati tista predhodna spoznanja, razlage, dejstva, stališča oziroma mnenja različnih strok, ki so pomembna, čeprav pogosto ni lahko opredeliti razlik med pomembnimi in obrobnimi pojavi in procesi oziroma pomembnimi in nepomembnimi podatki o prostorskemu razvoju. Gre za neko obliko povzetkov tistega, kar je bilo že razloženo, za ugotovitve o empirični naravi, regularnosti, hipotezah in ugotovitvah sintetične narave na področju prostorskega razvoja. Zato se najpogosteje opiramo predvsem na poskuse strokovnih razlag. Zato je analiza usmerjena predvsem na sintezo spoznanj in strukturiranje opisa posameznih sestavin. Prikazana je v obliki spoznanih dejstev, procesov, teženj in ocen prostorskega razvoja. Dejstva govorijo o stanju, procesi o preteklosti, težnje o prihodnosti (retrodikcija je razlaga za nazaj, prognoza je razlaga za naprej).

Za posamezna dejstva, procese, težnje in ocene poskušamo izluščiti tudi vzroke in možne posledice ter možne kazalce, s katerimi so opisane prostorske razmere. Ugotoviti želimo trdne in objektivne zveze med vzroki in učinki oziroma posledicami, saj vsebujejo strokovne razlage tudi iskanje vzrokov kot razlogov za pojave. Pri tem je seveda lahko sporno, če se analize vzrokov začnejo z vzrokom in nadaljujejo z iskanjem posebnih vzročnih razlag. Vzročne razlage temeljijo namreč na nespremenljivem in stalnem poteku stvari (kadarkoli obstaja vzrok, mu sledijo tudi ustrezne posledice), na prostorskem stiku med pojavi in procesi, na časovnem zaporedju (najprej vzrok in nato posledica) in ne nazadnje na asimetričnem razmerju vzročne poti. To gledanje izhaja iz stare antične tradicije, po kateri so vzroki stvari, pojavi, procesi itd. Vzroki so kompleksi nujnih ali/in zadostnih pogojev za nastanek nekega dejstva, kjer imajo poseben pomen zakoni in ne stvari. Vzročne razlage $\mathrm{v}$ strokovnem pomenu kot deduktivno-zakonske razlage temeljijo na zakonih o »sukcesiji« pojavov, ne pa na sočasni funkcionalni zvezi pojavov. Pri vzročnosti se pojavlja tudi vprašanje o njeni povezanosti z determinizmom, saj ne poteka vse po vzročnih zakonih, poleg tega pa niso vsi pojavi determinirani z zakoni in preteklimi stanji.

Opredelitve v analizi temeljijo torej na dejstvih o prostoru, ki so rezultat raziskovanj številnih strok. Dejstva pa morajo biti veljavna, to je točna, pravilna, preverjena in pridobljena predvsem iz primarnega vira, in sicer ne glede na to, ali so rezultat stvarnih prostorskih razmer ali zgodovinskih dokumentov. Avtentična dejstva o prostoru tvorijo strokovno podlago oziroma ji dajejo znanstveni značaj. Pri tem se najpogosteje opiramo na posamezne definicije prostorskih pojmov, ki podajajo bistvo kakšnega pojava in vsebujejo njegove nujne in zadostne znake, oziroma na nekatere nominalne (definicija pomena pojma) in konvencionalne (dogovor o rabi določenih izrazov) ter genetične (navajajo genezo stvari ali pojava) definicije. Ni namreč nujno, da nam definicije podajajo bistvene poteze stvari ali pojava, marveč je dovolj, če nam omogočajo bolj učinkovito rabo določenih izrazov.

$\mathrm{Na}$ podlagi omenjenega metodološkega pristopa prikazujemo korake pri strokovni analizi v prostorskem planiranju, ki smo ga uporabili pri pripravi strokovnih gradiv za Stra- 
tegijo prostorskega razvoja Slovenije na Uradu RS za prostorsko planiranje, in sicer v naslednjih vsebinskih sklopih:

- analiza stanja;

- ocena stanja;

- razvojne možnosti;

- prostorske vizije;

- inačice prostorskega razvoja.

\section{ANALIZA STANJA - PROSTORSKI PROBLEMI}

Analiza nekako opozarja na obstoječe stanje in prostorske probleme oziroma nezaželene razmere in pogoje, na prihodnje prostorske razmere in pogoje.

Namen analize stanja in teženj prostorskega razvoja je predvsem $v$ analitičnem opisu stanja. Analiza je usmerjena predvsem na sintezo spoznanj in strukturiranje opisa stanja $\mathrm{v}$ posamezne njene sestavine. Stanje prostorskega razvoja je zato prikazano v obliki spoznanih dejstev (brez vrednostnih sodb), procesov, teženj in ocen. Ocene stanja in teženj prostorskega razvoja so opredeljene namreč kot ključna vprašanja ali problemi prostorskega razvoja.

Med temi elementi analize stanja (dejstvo, proces, težnja, ocena) je nedvomno najpomembnejša ocena, ki na nek način izraža odnos do stanja, in sicer na podlagi dosedanjih strokovnih spoznanj, izkušenj, praktičnih podobnih primerov ali na podlagi opredeljene metode ocenjevanja, z vsem potrebnim kriterialnim instrumentarijem. Ocena stanja nam daje namreč vpogled $\mathrm{v}$ vrednotenje prostorske strukture $\mathrm{z}$ vidika meril za ocenjevanje, ko poskušamo oceniti ali so določeni pojavi in procesi relativno ugodni, primerni, zaželeni ali nezaželeni, z negativnimi ali pozitivnimi predznaki oziroma možnimi posledicami itd.

Ocene so pomembne tudi z vidika poskusov reševanja tistih razmer, ki so opredeljene kot ključna in najbolj pereča vprašanja stanja in teženj nadaljnjega prostorskega razvoja. $\mathrm{Na}$ podlagi ocene iščemo namreč možne rešitve.

Soočeni smo z veliko raznolikostjo/raznovrstnostjo in kompleksnostjo tako imenovanih »prostorskih problemov«, kar vpliva na številne možne vidike njihovega opredeljevanja. Njihov značaj je izredno kompleksen, saj je število dejavnikov lahko zelo veliko in najpogosteje so v razmeroma tesni povezanosti in soodvisnosti. Le malo je prostorskih problemov, ki jih lahko ločimo in reduciramo na omejeno število dejavnikov in medsebojnih razmerij, ki bi imela samo enorazsežnostni vrednostni sistem. Obstajata vsaj dva splošna načina za opredeljevanje prostorskih problemov. Z deskriptivnim pristopom poskušamo opredeljevati prostorske probleme na podlagi različnih vidikov: strokovnega, tehničnega, političnega, uradniško-administrativnega, zakonskega, sektorskega itd. Vsak vidik ima seveda tudi lastno opredelitev, kaj prostorski problem je in kakšne so njegove značilnosti. Nato sledi presoja/ocena/vrednotenje, oblikovanje rešitev, ukrepi in rezultati. Z normativnim pristopom pa opredeljujemo prostorske probleme znotraj določenega konteksta, in sicer $\mathrm{z}$ vidika smotrnosti (teleološki vidik) oziroma strokovnih načel, kodeksov, norm oziroma strokovne etike (deontološki vidik). Pri prvem vidiku opredelitve in rešitve prostor- 
skih problemov preverjamo z vrednotenjem posledic, pri drugem pa na podlagi deontološkega vrednotenja (Hendler, 1990).

Ker je načinov oziroma metod, s katerimi lahko opredeljujemo prostorske probleme, zelo veliko, je toliko tudi njihovih možnih razlag. Glede na različne razlage pa so seveda možne tudi zelo različne rešitve. To pomeni, da smo pred številnimi možnimi rešitvami. Ne obstaja samo ena sama rešitev za prostorske probleme. Lahko bi celo rekli, da za te probleme na splošno ne obstajajo prave ali napačne rešitve. Rešitve so samo dobre ali slabe, relativno glede druga na drugo in glede na vrednostni sistem, znotraj katerega jih rešujemo. Odvisne so predvsem od možnih ciljev reševanja prostorskih problemov, med drugim tudi od tega, ali želimo prostorske probleme:

- $\quad$ preprečiti, z delovanjem na vzroke, ki povzročajo njihovo nastajanje;

- $\quad$ preusmerjati v zaželene in možne oblike, funkcije in strukture;

- omiliti oziroma zmanjšati njihov prostorski obseg, intenzivnost, čas trajanja;

- $\quad$ spremeniti njihov relativni pomen oziroma težo;

- $\quad$ upočasniti nekatere njihove nezaželene procese;

- odpravljati njihove negativne vplive oziroma posledice;

- $\quad$ spremeniti njihove nezaželene pojavne oblike itd.

Prostorski problemi niso predvsem vprašanja »disciplin«, marveč vprašanja usmerjanja, spreminjanja, posameznih pojavov in procesov oziroma razvojnih teženj v skladu z možnimi cilji prihodnjega prostorskega razvoja in ne nazadnje vprašanja izboljšanja prostorskih pogojev življenja in bivanja. Če se strinjamo, da je pojav degradiranih urbanih območij v slo-venskih mestih eden izmed prostorskih problemov, se moramo spopasti še z vprašanjem glede različnih možnih načinov reševanja tega prostorskega problema: $\mathrm{z}$ regeneracijo, revitalizacijo, sanacijo itd.

Stvari so lahko razmeroma enostavne, če imamo jasna stališča, kaj so prostorski problemi, kakšna sta njihov značaj in pomen, kaj želimo narediti z njimi in ne nazadnje seveda tudi, kako naj to naredimo. Z večjimi težavami se lahko srečujemo, ko nimamo jasno izoblikovanih stališč glede omenjenih vprašanj, vemo pa, kako bi se lotili alternativ. V najslabšem položaju se lahko znajdemo, ko nimamo na voljo niti enotnih stališč, niti ne vemo, kako se lotiti stvari.

Prostorski problemi se torej razlikujejo med seboj po številnih nejasnostih, ki se nanašajo na različne možne načine za njihovo opredeljevanje in reševanje in ne nazadnje na možne končne rezultate. Nezanesljivost je temeljna značilnost vseh prostorskih problemov (Christensen, 1985). Zato velja postaviti jasne okvirje, ki delujejo kot neki stabilen element, na katerega se lahko opremo pri opredeljevanju, obravnavanju in reševanju prostorskih problemov. Za reševanje prostorskih problemov je potrebno oblikovati jasna načela, izhodišča in cilje, na podlagi katerih bo mogoče nedvoumno prepoznavati prostorske probleme in sprejemati ustrezne odločitve za rešitve prostorskih problemov v skladu z dolgoročnimi cilji prostorskega razvoja (Faludi, 1996).

Verjetno je najprimernejši začetek jasen kontekst, znotraj katerega opredeljujemo in rešujemo prostorske probleme. Številni menijo, da se mora planiranje nanašati v bistvu na konceptualne okvirje, ki omogočajo urejanje kompleksnosti. 
Značaj prostorskih problemov se kaže torej v naslednjih spoznanjih:

- $\quad$ prostorske probleme je težko dokončno opredeliti;

- $\quad$ opredelitev in razumevanje prostorskih problemov pomeni lahko več ali manj že tudi njihovo rešitev;

- $\quad$ za prostorske probleme ne obstajajo prave ali napačne rešitve;

- $\quad$ izredno težko je spoznati, kdaj so prostorski problemi rešeni;

- zelo veliko je načinov oziroma metod s katerimi lahko opredeljujemo in rešujemo prostorske probleme;

- $\quad$ obstajajo številne možne razlage za prostorske probleme;

- $\quad$ glede na različne možne razlage so možne tudi zelo različne rešitve;

- $\quad$ izredno težko je spoznati ravni prostorskih problemov;

- $\quad$ prostorski problemi se lahko kažejo kot simptomi drugih problemov;

- $\quad$ potem, ko smo poiskali rešitev za prostorske probleme, se ne moremo več vračati nazaj na prvotno stanje v katerem smo to rešitev oblikovali.

Za prostorske probleme so značilni torej:

- notranja povezanost: vsak prostorski problem je na nek način povezan z ostalimi problemi, in sicer tudi na različnih prostorskih ravneh;

- $\quad$ kompleksnost: pri prostorskih problemih obstajajo različni možni načini analiziranja in različni pristopi ter načini ukrepanja;

- negotovost: prostorske probleme opredeljujemo v dinamičnih in negotovih razmerah;

- dvoumnost: ne obstaja samo ena pravilna razlaga ali ena sama rešitev za prostorski problem;

- konfliktnost: konflikti med različnimi interesi na različnih področjih in različnih območjih so neizbežni pri iskanju, sprejemanju in opredeljevanju rešitev;

- omejitve: na izbiro načinov za reševanje prostorskih problemov lahko pomembneje vplivajo različne družbene, organizacijske, institucionalne, pravno-formalne, tehnične, politične ovire oziroma možnosti.

Iz strokovnih opredelitev izhaja, da so pri načrtovanju prostorskega razvoja med najbolj perečimi vprašanji predvsem: pomanjkanje filozofije o prostorskemu razvoju in urejanju, pomanjkanje prostorske vizije Slovenije, neustrezne pravne in upravne podlage prostorskega razvoja, odsotnost regionalne ravni planiranja, odnos do Evrope in sosednjih držav, neusklajenost planiranja sektorjev, neurejen infrastrukturni sistem, prostorski razvoj mest in naselij (razvrednotenje grajenega okolja, kakovost bivanja, urejanje naselij, stanovanja), funkcije podeželja in suburbanizacija. Na občinski ravni gre najpogosteje za težave, ki so povezane $\mathrm{z}$ zastarelo in neučinkovito zakonodajo in pomanjkanjem podzakonskih aktov, razmejitvijo pristojnosti med državo in lokalno skupnostjo, možnostjo pridobivanja zemljišč za izvajanje občinskih planov, neusklajenostjo planov z dejanskimi potrebami, poenostavitvijo planerskih postopkov, združitvijo izdaje lokacijskega in gradbenega dovoljenja itd.

Prostorski problemi se nanašajo predvsem na: (a.) zakonodajo, (b.) instrumente, (c.) planiranje, (d.) geopolitični položaj Slovenije, (e.) poselitev, (f.) infrastrukturo in (g.) krajino ter varstvo okolja. Vseh 730 ključnih obstoječih in pričakovanih prostorskih problemov 
je bilo razvrščenih po pomenu ter po številu oziroma pogostosti odgovorov v posameznih kategorijah.

(a.) Na področju zakonodaje so najbolj poudarjeni: neustreznost prostorske zakonodaje ter razmejitev pristojnosti med državo in lokalno skupnostjo, nefunkcionalni institucionalni sistem ter problemi v lokalni samoupravi.

(b.) Med glavne probleme na področju planerskih instrumentov so uvrščeni slabo stanje prostorskih dokumentov, pomanjkanje nadzora in ustreznih kazni za kršitelje ter pomanjkanje usmerjevalnih in spodbujevalnih instrumentov.

(c.) Največji problem na področju planiranja je neustrezna zemljiška politika in neenakomeren regionalni razvoj ter neusklajenost planiranja sektorjev. Med ostalimi problemi imajo posebno težo še strokovna neusposobljenost, slaba osveščenost javnosti, pomanjkanje razvojne vizije in vrednostnih meril ter slaba politika na vseh področjih ravnanja s prostorom.

(d.) $\mathrm{Z}$ vidika geopolitičnega položaja je $\mathrm{v}$ ospredju potreba po večjem varovanju nacionalnih interesov ter vzpostavitev dobrih mednarodnih odnosov. Sam položaj Številne prednosti geopolitičnega položaja se lahko kažejo tudi v negativnem smislu, in sicer predvsem v obliki tranzitnih koridorjev za velike evropske infrastrukturne sisteme in s tem nadaljnjih težnjah po razvoju samo osrednjega dela.

(e.) Na področju poselitve je omenjenih zelo veliko problemov, med njimi pa predvsem negativno razvrednotenje grajenega okolja. Sam sistem poselitve je slab zaradi nejasne vloge središč v omrežju, zaradi pojava razpršene poselitve in razpršene gradnje oziroma stihijske in črne gradnje. V ospredju je tudi stanovanjska problematika. Nič manj pomembni niso problemi razvoja naselij na podeželju.

(f.) Poglavitni problem na področju infrastrukture je predvsem neuravnotežen in nepovezan prometni sistem oziroma nepovezanost njegovega omrežja ter neusklajenost tega omrežja s poselitveno strukturo. Ponekod je infrastrukturna opremljenost slaba. Velik poudarek je dan ravnanju z odpadki.

(g.) Pri krajini in varstvu okolja je zelo problematično razvrednotenje krajinskega prostora, neracionalna raba prostora in neustrezno varovanje naravne in kulturne dediščine ter zaraščanje kmetijskih zemljišč. Zelo pereče je neustrezno izkoriščanje vodnih virov in mineralnih surovin, onesnaženost okolja, ogroženost pred naravnimi procesi in preobremenjenost obale.

Ključni obstoječi in pričakovani prostorski problemi se z vidika rabe zemljišč nanašajo na nesmotrno, neusklajeno, neučinkovito, neracionalno, neuravnoteženo, stihijsko in potratno rabo zemljišč.

Obstajajo velike razlike v razvitosti posameznih območij, ki se izražajo v različnih pogojih za življenje in delo (velike razlike v razporeditvi delovnih mest, stopnji brezposelnosti, v izobrazbeni strukturi prebivalstva), $v$ neustrezni prometni povezanosti med regijami in v neenakomerni dostopnosti do družbene infrastrukture znotraj regij.

Prometna infrastruktura ne zagotavlja ustrezne prometne povezanosti in dostopnosti, predvsem med obmejnimi regijami in znotraj regij, kar vpliva tudi na pomanjkljivo dostopnost perifernih območij. K temu prispeva tudi neustrezna razvrstitev in razmestitev prometnih vozlišč in njihovih medsebojnih povezav. Primanjkuje učinkovitih povezav med prome- 
tnimi omrežji, predvsem med prestopnimi točkami javnega potniškega prometa in med terminali za blagovni promet. Razmerja med cesto in železnico so neugodna, kar velja tudi za omrežje in frekvence javnega prometa.

V krajinskih območjih se zmanjšuje stopnja naravne ohranjenosti, vizualna kakovost, ter produktivnost in raznolikost krajine. $\mathrm{V}$ krajini poteka neracionalna raba naravnih virov. Zapostavljena je krajinska identiteta.

Neuravnoteženo urbano omrežje se kaže $\mathrm{v}$ neustreznem položaju središč znotraj območij ali neustrezni prostorski členitvi regij, njihovi velikosti in opremljenosti. Problemi neuravnotežene prostorske razmestitve gospodarske in družbene infrastrukture ter strukturna nesorazmerja med posameznimi regijami in regionalnimi središči se kažejo v slabši dostopnosti posameznih območij in naselij, v obsežnih vsakodnevnih migracijah ter v neučinkoviti, dragi in pomanjkljivi infrastrukturni opremljenosti. Slaba dostopnost do storitev višje ravni je še posebej značilna za obmejna območja. Poselitvena območja se srečujejo z velikimi pritiski na širša zaledja mest in kakovostnejša krajinska območja, tudi v obliki nelegalnih gradenj. Neustrezna je funkcionalna členitev mest in nizka raven urbaniziranosti, ki vpliva na neracionalno komunalno infrastrukturo. Nastala so obsežna degradirana območja (rudarska, industrijska, manj vredna stanovanjska).

Sistem regulacije prostorskega urejanja in razvoja je neučinkovit, primanjkuje instrumentov za izvajanje prostorske politike in planov, izobraževanje je nesmotrno, informacijski sistemi in vhodni podatki za pripravo prostorskih planov so nedorečeni, pristop k raziskovalnemu delu je nesistematičen, med različnimi prostorskimi ravnmi je pomanjkljivo medsektorsko sodelovanje in koordinacija med zemljiško in prostorsko politiko.

Prostorski razvoj je čedalje bolj rezultat spontanih in parcialnih interesov in pobud. Množijo se primeri neprimerne rabe zemljišč. Nastajajo neskladja in nasprotja med različnimi uporabniki prostora, bodisi javnimi (sektorji, občinami in državo) ali javnimi in zasebnimi ter med zasebnimi. Vse prevečkrat se prostorske probleme rešuje parcialno kar povzroča nova nasprotja. Zanemarja se ohranjanje naravne in kulturne dediščine in ostalih vrednot. Spregleduje se regionalne posebnosti. Zapostavljajo se potrebe po solidarnostni pomoči posameznim območjem.

Sistem urejanja prostora je bil zasnovan na želji po obvladovanju procesov v prostoru in ne toliko na predstavi o tem, kakšen naj bi prostor bil. Zasnovan je bil več ali manj na zadovoljevanju prostorskih potreb tako imenovanih porabnikov prostora in $\mathrm{v}$ popolni odsotnosti celovite predstave o želenem in možnem konceptu prostorskega razvoja. $\mathrm{K}$ temu je brez dvoma prispeval tudi sektorski način planiranja v obliki zadovoljevanja sektorskih potreb in sektorskega načina organizacije družbe v prostoru. Dosedanji način organizacije dejavnosti v prostoru je bil namenjen večinoma zadovoljevanju sektorskih potreb po prostoru. Proces priprave planskih dokumentov države in tudi občin je bil omejen zgolj na iskanje ustreznih lokacijskih rešitev za uresničevanje različnih razvojnih pobud. Neučinkovitost urejanja prostora je prihajala še posebno do izraza na področju razvoja naselij. Tudi obravnavanje krajine $\mathrm{v}$ dosedanjem sistemu urejanja prostora je bilo več ali manj parcialno.

Neučinkovitost in neustreznost urejanja prostora sta tudi posledica nesorazmerja med centralizacijo te dejavnosti na državni ravni in njene atomizacije na ravni občin. 
Problemi načrtovanja prostorskega razvoja se nanašajo predvsem na: neučinkovit sistem regulacije prostorskega urejanja in razvoja, probleme večravenskega sistema odločanja, pomanjkljivo medsektorsko sodelovanje, koordinacija med zemljiško in prostorsko politiko, med posameznimi prostorskimi ravnmi, pomanjkljive instrumente za izvajanje prostorske politike in planov, politično neučinkovit nadzor, nedorečeno zemljiško politiko, neracionalno gospodarjenje z zemljišči, potratnost rabe in neučinkovito rabo sredstev vloženih v zemljišča, preskromno ponudbo zemljišč za graditev, neusklajenost s planskimi predvidevanji, potratno poselitev in organizacijo dejavnosti v prostoru, nesmotrno izobraževanje, nedorečen informacijski sistemi in podatke za pripravo prostorskih planov in nesistematični pristop k raziskovalnemu delu za politično aplikacijo.

Opustitev dosedanjega sistema planiranja, zastarela zakonodaja, pomanjkanje strategije dolgoročnega prostorskega urejanja, neurejeni odnosi na področju urejanja prostora med državo in občino, neusklajenost med različnimi prostorskimi interesenti pri rabi prostora, nizka stopnja upoštevanja strokovnega znanja, pomanjkljivi in nedodelani prostorski informacijski sistemi nedvomno govori o razmeroma številnih, raznovrstnih in, več ali manj neugodnih pogojih ali celo posameznih pomembnih omejitvah za prostorske razvojne možnosti.

Priča smo praznjenju odročnih podeželskih, posebno hribovitih območij. Nekatera poseljena območja se praznijo. Neskladja med regijami se povečujejo. Regionalne razlike v stopnji razvitosti in razvojnih možnosti so še vedno precejšnje. Nekatere obrobne regije so ostale izven glavnega gospodarskega toka. Še vedno niso odpravljene znatne razlike med hribovskimi, obmejnimi ali geografsko odmaknjenimi ter osrednjimi predeli. Vedno več je depresivnih območij. Povečujejo se potrebe po prenovi degradiranih območij in izboljšanju slabih ekoloških razmer. V posameznih območjih opozarjajo na svojstvene probleme, kot so obmejnost, slaba prometna dostopnost, slabše razvite javne službe, šibka urbana središča, pogosto enostransko gospodarsko usmerjenost itd.

Pomanjkljivost na področju prostorskega razvoja se kaže tudi na regionalni ravni, in sicer v odsotnosti pokrajin oziroma v pomanjkanju koordinacijskih mehanizmov za vzpostavitev učinkovitega sodelovanja med državo, občinami, lokalno skupnostjo, gospodarskimi akterji in civilno družbo.

Iz omenjenega seznama je možno razumeti, da izhaja večina prostorskih problemov iz neurejenega sistema urejanja prostora. Vprašanje je, ali lahko večino ključnih obstoječih in pričakovanih prostorskih problemov pripisujemo tudi neurejenemu oziroma neustreznemu sistemu urejanja prostora? Ali prihaja do črnih gradenj zgolj zaradi nespoštovanja zakonskih in ostalih določil in dokumentov, ali zaradi tega ker sistemu urejanja prostora ne uspeva zagotavljati ustreznih površin za razvoj. Ali je posredi prepočasen, časovno zamuden, prezahteven, predrag, preveč zapleten postopek pri pridobivanju ustreznih dokumentov za gradnjo? Videti je, da je sedanji sistem urejanja prostora eden od vzrokov za nastajanje nekaterih prostorskih problemov, predvsem tistih, ki se nanašajo na možnosti hitrejšega uresničevanja takšnih ali drugačnih zahtev, potreb, pobud in interesov.

Zahteve po učinkovitem sistemu urejanja prostora se nanašajo namreč predvsem na planerske postopke, na hitrost pridobivanja takšnih ali drugačnih dokumentov, dovoljenj, soglasij in mnenj za »posege v prostor«. Kot, da je prostorsko planiranje sestavljeno samo 
iz različnih posegov, za katere je potrebno dobiti takšno ali drugačno dovoljenje. V kolikor je mišljena taka učinkovitost, potem bi veljalo za doseganje omenjenega cilja pripravljati take dokumente, ki bi kar v največji meri omogočali poenostavitev postopkov. Vprašanje pa je, kaj pomeni poenostavitev postopka. Med drugim gre lahko tudi za opuščanje določenih vsebinskih področij, določenih faz v postopkih, umikanje prostorskega planiranja iz določenih področij in tudi za zmanjševanje njegove pristojnosti.

Iz odgovorov je možno razbrati, da bi moral sistem urejanja prostora ponuditi torej take dokumente (oziroma tako vsebino) na podlagi katerih bi lahko prihajalo do nedvoumnih, jasnih, transparentnih odločitev. Ali drugače rečeno, imeti dokumente na podlagi katerih bomo lahko nesporno, v čim krajšem času, s čim manjšimi stroški, čim bolj usklajeno prihajali do odločitev zaradi zadovoljevanja potreb po razvoju.

To govori med drugim tudi o večjih zahtevah po prilagajanju sistema urejanja prostora potrebam in interesom oziroma zadovoljevanju različnih sedanjih in bodočih potreb družbe, posameznika, gospodarstva po zemljiščih za razvoj. Videti je, da »lakota po razvoju« ustvarja velike pritiske na zagotavljanje prostora za razvoj. S tega vidika bi lahko sklepali, da mora biti urejanje prostora osredotočeno na nameščanje (lokacije) dejavnosti in razvoja $\mathrm{v}$ prostoru. Mnenja kažejo na to, da bi moralo urejanje prostora ponuditi učinkovite mehanizme (instrumente), ki bi omogočili, da bi s čim manj konfliktov zadovoljevali različne potrebe in interese, in zagotavljali ustrezne oziroma primerne konkretne rešitve na vseh prostorskih ravneh.

Neprestano zadovoljevanje zahtev, potreb, pobud in interesov lahko vodi v številne konflikte, poleg tega pa je soočeno tudi s številnimi omejitvami. Mogoče bi moralo ravno urejanje prostora jasno določiti te meje in omejitve, saj ima prostor omejene, čeprav spremenljive možnosti za sprejemanje razvojnih zahtev, pobud in interesov. Prostor nima neskončnih možnosti za nameščanje razvoja. Poleg tega pa prostor ni namenjen zgolj nameščanju razvoja, saj je namenjen tudi samemu sebi.

\section{OCENA STANJA}

Posebno teoretično, metodološko in vsebinsko področje je izdelava ocene stanja, dejstev, procesov in teženj prostorskega razvoja. Ocene o stanju in težnjah v prostorskemu razvoju se nanašajo na prostorske probleme in s tem nekako zagotavljajo informacije za opredeljevanje ciljev, vrednot in prioritet, hkrati pa pomagajo določiti, katera dejstva in problemi so relevantni. Pomisleki o ocenjevanju prostorskega razvoja obstajajo pravzaprav samo do takrat, dokler ne opredelimo vloge oziroma pomena prostorskega razvoja, njegovega bistva in predmeta ter tudi samega procesa prostorskega razvoja.

Brez jasnih stališč do omenjenih vprašanj je opredeljevanje stanja bolj ali manj zgolj opis (ugotovitev, spoznanje) obstoječih dejstev, razmer in pogojev (opis obstoječih značilnosti, stanja, položaja) brez kakršnegakoli stališča (mnenja), zakaj so ti pogoji oziroma razmere pomembne. Vrednostne sodbe in vrednote ne igrajo vloge dejstvenih sodb ali dejstev v razlagah. Opredeljevanje ciljev npr. pomeni identifikacijo sedanjih in prihodnjih problemov, opredeljevanje teženj v obliki namenov in ciljev ter opredeljevanje strateških vprašanj in prioritet med njimi. 
Med splošne cilje prostorskega razvoja nedvomno sodijo: enakost, varovanje ustavnih pravic, možnost izbire, okoljska kakovost, kakovost življenja, zdravje in varnost, učinkovitost in izvedljivost. Enakost se nanaša na distribucijo stroškov in koristi javne politike oziroma javnih politik. Varovanje ustavnih pravic pomeni, da morajo biti pri rabi prostora upoštevani zakoniti cilji. Možnost izbire pomeni zagotavljanje različnih vrst prostora, gostot, lokacij in tipov. Okoljska kakovost se nanaša na kakovost zraka, vode in zemljišč ter ustvarjenega okolja. Kakovost življenja je cilj, ki izraža neekonomske, manj jasne in manj kvantificirane kategorije splošne blaginje skupnosti. Zdravje in varnost se nanašata na nevarnosti za zdravje in pojavljanje poškodb ter na promocijo fizične in emocionalne blaginje. Učinkovitost in izvedljivost pa sta cilja, ki se nanašata na razvojna merila. Učinkovitost se nanaša na sposobnost predlagati rešitve, da dosežemo cilj; ali predlog res opravlja tisto, za kar je predlagan; ali prostorska zasnova dosega cilje oziroma zaželeni prostorski vzorec; ali strategija izvajanja dosega zastavljene cilje; ali prostorski razvoj poteka ob čim manjši rabi prostora, časa, energije in finančnih sredstev oziroma ali so prostorske rešitve v skladu $\mathrm{s}$ primernimi razmerji med njimi?

Kakovost prostora je torej tista, ki prispeva k spremembam v obliki trajnega razvoja posameznika, skupnosti kot celote in njihove kulture: razvoj so vse možnosti, ki so odprte za vse prebivalce, na podlagi katerih lahko uživajo materialno in duhovno prosperiteto. Gre za proces, ki vodi v vedno večjo kompleksnost, bogatejše povezave, višjo pristojnost za doseganje in realizacijo fizičnih, družbenih, intelektualnih in emocionalnih sposobnosti. Kakovost prostora je torej odprta dinamična struktura: dostopna (povezana), decentralizirana, raznolika in prilagodljiva - v nasprotju s težnjami po stabilnem prostoru.

\section{ANALIZA PROSTORSKIH RAZVOJNIH MOŽNOSTI}

Prostorske razvojne možnosti obravnavamo najpogosteje kot enega izmed elementov postopkov pri pripravi strokovnih gradiv za sprejemanje odločitev o prostorskih razvojnih konceptih, in sicer znotraj konteksta tako imenovanega racionalnega planerskega modela.

Analiza prostorskih razvojnih možnosti sodi v analitični del priprav strokovnih gradiv in tvori eno izmed faz cikličnega pristopa, ki temelji na sprotnem preverjanju in vrednotenju rezultatov strokovnega dela in njihovemu nadaljnjemu vključevanju v pripravo skupnih strokovnih podlag. Gre torej za ciklični in ne linearni pristop k metodi vrednotenja.

Metodološka in vsebinska priprava pa se nanaša na opredeljevanje politike prostorskega razvoja, ki določa temeljna načela, izhodišča in cilje prostorskega razvoja ter prostorskega plana, ki določa vizijo, koncept in zasnovo prostorskega razvoja ter strategijo za njegovo izvajanje. Zato je analiza prostorskih razvojnih možnosti zasnovana najpogosteje v dveh korakih. Prvi je namenjen spoznavanju tistih prostorskih razvojnih možnosti, ki so opredeljena na ravni strokovnih analiz. Drugi korak pa je namenjen primerjalni analizi in poskusu ocene prostorskih razvojnih možnosti.

Prostorske razvojne možnosti se nanašajo v prvi vrsti na prostorske pogoje, potenciale in omejitve ter posamezne prostorske kategorije, oblike, funkcije in prostorske strukture. Hkrati pa se nanašajo tudi na splošne družbene, gospodarske, socialne, institucionalne in 
pravno formalne razmere ter tehnično-tehnološke možnosti. Prostorske razvojne možnosti se nanašajo na zelo različne kategorije, na oceno okolja, opis dejstev ali spoznanja o dejstvih, analizo problemov, pretresanje obstoječih razmer in analizo relevantnih pogojev ali informacijsko podlago.

Prostorske razvojne možnosti se seveda razlikujejo tudi glede drugih razsežnosti. Nekatere prostorske razvojne možnosti so razpoznavne in se nanašajo na pretekle in sedanje pogoje. Druge prostorske razvojne možnosti so projekcije bodočih pogojev. Nekatere prostorske razvojne možnosti so značilnost prostorskih struktur, druge se nanašajo na zunanje dejavnike, ki vplivajo na sedanji in prihodnji prostorski razvoj. Nekatere prostorske razvojne možnosti so neposredno obvladljive, drugi ne. Nekatere prostorske razvojne možnosti izhajajo iz znanstvenih raziskav in vedenj, nekatere izhajajo iz vsakdanjega vedenja in izhajajo iz osebnih izkušenj, opazovanj ali raznih razprav.

Pozornost analize prostorskih razvojnih možnosti je usmerjena na dejstva o sedanjih razmerah, težnjah in možnih prihodnjih pogojih. V strateškem planiranju se ta dejavnost nanaša na pretresanje zunanjih in notranjih razmer zaradi opredeljevanja oziroma spoznavanja ključnih dejavnikov in teženj ter opredeljevanja zunanjih sil, ki bodo verjetno vplivali na razmere $v$ skupnosti.

Predvidevanja oziroma napovedovanja se nanašajo v prvi vrsti na dejavnike in pogoje, ki so več ali manj predvidljivi in jih lahko ocenimo s tehnikami projekcij, kot so razmerja, ekstrapolacije in simulacije. Zasnova scenarijev pa je na drugi strani bolj raziskovalna predstavitev alternativne prihodnosti, ki naj bi se pojavila oziroma v normativnem smislu mogoče celo res pojavila. Scenariji raziskujejo alternative prihodnosti, posebno v zunanjih okoljih, a tudi v nenadzorovanih razmerah $\mathrm{v}$ skupnosti - npr. ali bo gospodarstvo prosperiralo, počasi naraščalo ali nazadovalo; ali bo turizem še naprej tvoril pomemben sektor gospodarstva; ali bo tehnologija odpadnih vod vplivala na manjšo stopnjo odvisnosti od obstoja javnega komunalnega sistema. Scenarije lahko uporabljamo v povezavi s projekcijami zaradi ocene verjetnih prihodnjih pogojev in pri tem uporabljamo koncepte nizkih in visokih projekcij, najslabših in najboljših pogojev, močnih ali šibkih vplivov itd.

Opredeljevanje prostorskih razvojnih možnosti poteka sočasno s pripravo prostorskega razvojnega konteksta, ki je opredeljen na podlagi temeljnih načel in dolgoročnih ciljev prostorskega razvoja ter na vizijah in konceptih prostorskega razvoja. Opredeljevanje prostorskih razvojnih možnosti brez upoštevanja temeljnih načel in ciljev prostorskega razvoja pomeni, več ali manj zgolj opis (ugotovitev, spoznanje) »obstoječih ali predvidenih pogojev«, in sicer brez kakršnega koli stališča o tem, zakaj so ti pogoji oziroma razmere pomembne.Temeljna načela za preverjanje prostorskih razvojnih možnosti se nanašajo na suverenost odločanja, trajnostni in endogeni razvoj, splošne družbene vrednote, decentralizacijo in participacijo pod enakimi pogoji na različnih ravneh odločanja, znanstveni in strokovni pristop ter na spoštovanje mednarodnih meddržavnih ter regionalnih pogodb in dogovorov. Splošni cilji prostorskega razvoja pa so naravnani na izboljšanje kakovosti življenja in fizičnega okolja, zagotavljanje trajnostnega razvoja in razvojnih priložnosti in pogojev za vse prebivalce.

Prostorske razvojne možnosti so predpogoj za razmišljanja o sprejemanju odločitev o oblikovni, funkcijski in strukturni zasnovi prostorskega razvoja oziroma prostorskih raz- 
merij med posameznimi prostorskimi kategorijami in funkcijami (npr. razmerja med urbanimi, suburbanimi in ruralnimi območji oziroma razmerja med urbanim in odprtim prostorom).

Prostorske razvojne možnosti so opredeljene na podlagi strokovnih analiz in sicer z vidika:

- analiz obstoječega stanja in razvojnih teženj v prostoru;

- analiz problemov dosedanjega prostorskega razvoja;

- temeljnih predpostavk o prihodnjem razvoju;

- možnih posledic prihodnjega razvoja;

- možnega doseganja splošnih ciljev prostorskega razvoja;

- znanih in predvidenih pogojev, potencialov in omejitev.

Prostorske razvojne možnosti so lahko prikazane v zelo različnih oblikah, med drugim tudi v obliki:

- $\quad$ vizij (prostorska razvojna vizija na državni ravni in ravni regij),

- scenarijev (trend, tehnološki, optimalni in konzervativni scenarij ter scenarij periferna fragmentacija; razpršeni, policentrični scenarij in scenarij oblikovanja razvojnih osi poselitve),

- modelov (normativno varstvo, normativno varstvo in vključevanje varstvenih ciljev v postopke načrtovanja, uresničevanje varstvenih ciljev samo $\mathrm{z}$ vključevanjem $\mathrm{v}$ postopke načrtovanja; model prednostnega varstva vrednot in minimalnega razvoja, model prednostnega razvoja in minimalnega varstva vrednost, model srednje stopnje varstva in razvoja; model decentralizirane zgostitve poselitve),

- alternativnih možnosti prostorskega razvoja,

- konceptov (koncept spodbujanja regionalnega razvoja; prednostno razvojni-prevladujoči razvojni interesi, prednostno varovalni, prevladujoči varovalni interesi, razvojno varovalni - uravnoteženo razmerje med razvojnimi in varovalnimi interesi; monocentrizem, policentrizem, razvojne osi omrežja središč; primarni, sekundarni in terciarni koncepti ter sintezni koncepti na državni, makroregionalni, mezoregionalni in mikroregionalni ravni; nepolarizirani (spontani) in polarizirani koncept poselitve, regionalistični in univerzalistični koncept poselitve),

- določanja planskih območij (območja varstva vrednot, zadržanega razvoja, usmerjenega razvoja in posebnih območij);

- nacionalnih strategij in programov (možnih lokacij energetskih omrežij in objektov, predvidenih lokacij za obvezne rezerve naftnih derivatov, infrastruktura, gospodarstvo);

- ciljev in usmeritev sektorjev pri zadovoljevanju lastnih razvojnih potreb. (Černe, Kušar, 2002)

Načini spoznavanja prostorskih razvojnih možnosti so številni, raznovrstni in kompleksni. Ravno zaradi tega številni avtorji zagovarjajo opredeljevanje prostorskih razvojnih možnosti predvsem na podlagi:

- selektivnega pristopa;

- opredelitve prioritet; 
- opredelitve ciljev za reševanje;

- zasnove strategij za doseganje ciljev.

V kontekstu analize prostorskih razvojnih možnosti opredeljujemo omenjene možnosti iz naslednjih vidikov:

- doseganja ciljev prostorskega razvoja;

- reševanje ključnih prostorskih razvojnih problemov;

- opravljanje nezaželenih pojavov in procesov;

- odpravljanje nezaželenih posledic prostorskega razvoja;

- prostorskih razvojnih omejitev;

- prihodnjih pogojev prostorskega razvoja.

Spoznavanje prostorskih razvojnih možnosti s teh vidikov omogočajo oblikovanje odgovorov o tem, kakšne so možnosti prostorskega razvoja za:

- aktivno poseganje v razvojni proces zaradi doseganja zaželenih ciljev;

- možnega ustvarjanja takih prostorskih razmer, ki se lahko neprestano prilagajajo spremembam oblik, funkcij in struktur prostora $\mathrm{v}$ različnih časovnih obdobjih;

- spodbujanje pestrega, kakovostnega in polnega življenja v vsakem kraju in v vsaki regiji;

- ustvarjanje funkcijske učinkovitosti, okoljske in varstvene naravnanosti ter estetske slikovitosti prostorskih struktur;

- različne prostorske oblike razvoja: prostorsko koncentracijo/dekoncentracijo, prostorsko centralizacijo/decentralizacijo, prostorsko razpršenost, koncentrirano decentralizacijo, linijsko/linearni/koridorsko, omrežno, točkovno/nodalno/;.

- zagotavljanje kakovostnega prostorskega razvoja brez potratne rabe površin (več prostora $\mathrm{z}$ manjšo potratnostjo) oziroma take prostorske strukture, ki omogoča najboljšo prostorsko razporeditev poselitvenih območij (stanovanj), delovnih mest in infrastrukture v takem prostorskem vzorcu, ki bo kar v največji možni meri varoval odprti prostor. Če je prostorski razvoj usmerjan (voden) v razumna in logična razvojna območja, ki tvorijo privlačne urbane skupnosti različnih velikosti, ki so ustrezno prostorsko razmeščene, potem bo ostalo zadosti prostora $\mathrm{v} v$ seh regijah za kakršne koli nadaljnje potrebe in razvoj, in to ob dejstvu, da bo večji del prostora ostal odprt prostor;

- obvladovanje prostorskega širjenja razvoja, ki pomeni čim manjši obseg novih zemljišč za razvoj in hkrati doseganje čim bolj kompaktnega razvoja znotraj obstoječih površin. To pomeni tudi zmanjševanje stopnje tistih prostorskih sprememb, ki zahtevajo obsežna odpiranja čisto novih zemljišč za razvoj. To pa zahteva rehabilitacijo, reciklažo in sanacijo obstoječih struktur, ki lahko povečajo prostorske razvojne možnosti (razvrednotena mestna in primestna območja, podeželska ravninska območja intenzivnega kmetijstva, hidromelioracij, kraška gorska območja intenzivnega turizma in rekreacije, obalno območje);

- spodbujanje tistih prostorskih sprememb, ki so v skladu s prostorom kot celoto oziroma v skladu s fizičnimi in ustvarjenimi vrednotami prostora; 
- ustvarjanje raznovrstnih oblik, funkcij in struktur ter take rabe zemljišč, ki omogoča prebivalcem, da so v različnih pokrajinah, krajih in naseljih zaradi različnih namenov, v različnem času, a hkrati uporabljajo številne skupne zmogljivosti in storitve;

- $\quad$ preseganje nekaterih razvojnih vplivov in posledic, ki so bili opredeljeni kot temeljni ključni problemi dosedanjega in predvidenega prihodnjega prostorskega razvoja;

- $\quad$ spreminjanje pogojev, izboljšanja, saniranja, preprečevanja vzrokov za nastajanje nezaželenih razmer in ustvarjanje novih pogojev in potencialov;

- $\quad$ vzpostavitev temeljev za koordinacijo razvojnih procesov decentralizacije na področju poselitve, proizvodnje in storitev;

- $\quad$ zasnovo prometnega sistema, ki bo odgovarjal oziroma sovpadal z razpršenim vzorcem poselitve in rabe zemljišč;

- $\quad$ preseganje nekaterih dosedanjih in predvidenih nezaželenih oblik, funkcij in struktur prostorskega razvoja, ki povzročajo številne probleme in težave;

- $\quad$ širjenje naselij na obrobju urbanih naselij, znotraj urbanih naselij, v novih urbanih območij ali v vaških naseljih;

- $\quad$ prostorsko usmerjanje amorfne poselitvene strukture, ki jo narekuje prevlada osebnega avtomobila, gradnja avto cest in sodobna telekomunikacijska tehnologija;

- omejevanje in preprečevanje razpršenih oblik gradnje stanovanj, delovnih mest in storitev po vsem ozemlju oziroma decentralizirano poselitev, kot temeljnega nosilca prostorskega razvoja, ki je hkrati tudi zaželena obliko bivanja. Pri tako imenovanemu enodružinskemu bivanju v decentralizirani pokrajini gre za razporeditev centralnih dejavnikov in elementov po celotni pokrajini. Koncept individualnega razvoja, kjer prebivalci lahko živijo in delajo ter se rekreirajo kjerkoli in kadarkoli pomeni, da ni kraja, ki bi bil priviligiran kot središče, kamor so prebivalci prostorsko usmerjeni (gre za nepomembnost osrednje lokacije kot točke oziroma območja komunikacije). Decentralizirana pokrajina pomeni, da sta delo in stanovanje razpršena po vsej pokrajini. Razpršena poselitev postane s tem univerzalna prostorska norma.

Šele na podlagi spoznavanja prostorskih razvojnih možnosti v razmerju do teh vprašanj lahko iščemo odgovore o tem, kakšne so razvojne možnosti. S tem pa še nismo odgovorili na vprašanje, kakšne so prostorske razvojne možnosti v različnih prostorskih, družbenih, gospodarskih in institucionalnih ter ostalih pogojih, ki se nanašajo na gospodarski razvoj (sistema zasebnega podjetništva in sodobnega konkurenčnega tržišča), družbeno pravičnost in varstvo okolja oziroma v kontekstu tržne in družbene racionalnosti oziroma učinkovitosti, ki brezpogojno upošteva človeške in okoljske stroške rasti? Ali z drugimi besedami, kakšne so prostorske razvojne možnosti v luči družbenih, gospodarskih in ekoloških vrednot ter koncepta trajnostnega razvoja in elementov sprememb ter relativne stabilnosti prostorske strukture?

$\mathrm{Na}$ prostorske razvojne možnosti obstajajo seveda zelo različni pogledi tako z vidika posameznih strok, sektorjev, posameznikov, kakor tudi predstavnikov civilne družbe, institucij na državni ravni in na ravni lokalne samouprave. Vsak s svojega zornega kota gleda na razvojne možnosti in jih tudi ocenjuje znotraj lastnih kontekstov in konceptov. Ravno zaradi te raznolikosti je potrebno razmišljati o številnih možnih opcijah in različicah znotraj 
konteksta doseganja zaželenih ciljev. To pa zahteva odgovor na vprašanje o tem, ali je potrebno spreminjati obstoječe razmere oziroma predvidene pogoje, oziroma ustvarjati drugačne pogoje in razmere v katerih bo potekal prostorski razvoj.

Gre za prostorske razvojne možnosti znotraj konteksta usklajevanja različnih razvojnih interesov, zahtev in potreb, in sicer z vidika zagotavljanja materialnih pogojev (zemljišč in infrastrukture) in uresničevanje zasebnih pobud na podlagi ustvarjanja primernega ravnotežja med potrebami po razvoju in interese varovanja. Gre za oceno možnosti o uresničevanju sektorskih pobud, želja, interesov, in sicer brez večjih konfliktov, usklajeno in uravnoteženo. Seveda pa se prostorske razvojne možnosti ne nanašajo samo na razmerje med tistimi, ki zagotavljajo prostor (zemljišča) in storitve (infrastruktura) in tistimi, ki izražajo takšne ali drugačne potrebe, saj gre tudi za urejanje prostora (v nekaterih primerih tudi za ne urejanje prostora) zaradi prostora samega, ne pa zaradi preskrbe s prostorom.

Zato moramo prostorske razvojne možnosti obravnavati v kontekstu objektivnih meril, stanja, načel in ciljev prostorskega razvoja, znotraj konteksta ciljev prostorskega razvoja, ki niso nič več in nič manj kot raznolik, relativno stabilen dobro uravnotežen in trajen razvoj, ki lahko zadovoljuje zahteve/potrebe vseh habitatov.

Drug pristop pri spoznavanju prostorskih razvojnih možnosti, predvsem pa njihovega ocenjevanja, poteka znotraj opredelitve meril vrednotenja, ki se lahko nanašajo na:

- $\quad$ ekonomske koristi: glede na prostorsko strukturo se ekonomska učinkovitost nanaša na koordinacijo javnega in zasebnega razvoja $\mathrm{v}$ tem smislu, da so potovanja iz kraja bivanja v kraj zaposlitve, iz kraja bivanja do šole, iz kraja bivanja do rekreacijskih območij, iz kraja bivanja ali kraja zaposlitve do storitvenih dejavnosti čim krajša; da ima industrija dober dostop do regionalnega prometnega omrežja; da prostorska razporeditev rabe zemljišč omogoča kar najlažjo oskrbo s pitno vodo, komunalnim sistemom, prometom in ostalimi storitvami; da so javne in zasebne dejavnosti energetsko učinkovite; $\mathrm{z}$ drugimi besedami, prizadevamo si za tako prostorsko strukturo znotraj katere je organizacija rabe zemljišč ekonomična za skupnost, za storitve in ekonomsko učinkovita za uporabnike zemljišč;

- $\quad$ varovanje zakonitosti: gospodarjenje z zemljišči mora spoštovati zakonite cilje, raba zemljišč pomeni razumna in učinkovita razmerja do teh ciljev, ki pa niso prekomerno represivna; gre za izogibanje prisvajanja lastnine brez prave kompenzacije, upoštevanje različnih interesov in prebivalcev v regij; enako in pošteno obračanje na vse ljudi v podobnih okoliščinah in ne diskriminiranje različnih skupin prebivalstva;

- možnost izbire: gre za zagotavljanje različnih vrst prostora, gostot, lokacij in tipov razvoja zaradi tega, da lahko prebivalci izbirajo kraje glede na njihov okus in žep;

- $\quad$ kakovost okolja: kakovost okolja se nanaša na kakovost zraka, vode in zemljišč ter ustvarjenega okolja;

- $\quad$ kakovost življenja: kakovost življenja je cilj, ki izraža neekonomske, manj jasne in manj kvantificirane kategorije blaginje skupnosti oziroma splošne blaginje skupnosti;

- zdravje in varnost: zdravje in varnost se nanašata na nevarnosti za zdravje in pojavljanje poškodb in na promocijo fizične in emocionalne blaginje;

- $\quad$ učinkovitost ter izvedljivost: učinkovitost in izvedljivost sta cilja, ki se nanašata na razvojna merila. Učinkovitost se nanaša na sposobnost predloga, da doseže cilj. Prep- 
rost test je $\mathrm{v}$ tem, ali predlog res opravlja tisto za kar je predlagan. Ali raba zemljišč dosega cilje, ki jih zasleduje prostorska zasnova? Ali sistem dosega zaželeni vzorec rabe zemljišč? Ali strategija izvajanja dosega cilje sprejetega plana?

- $\quad$ prostorske spremembe: planer mora opredeliti demografske in gospodarske spremembe, ki določajo »potrebe« po zemljiščih, stanovanjih, vodi, prometu, šolah, rekreacijskih zmogljivostih, čiščenju pitne vode, odlaganju odpadkov in drugih komunalnih storitvah. Spreminjanje rasti in sprememb v potrebah pomeni uporabljanje standardov, ki so na začetku lahko v obliki opcij, kasneje pa so lahko ocenjeni in izbrani v procesu opredeljevanja želja, interesov in razvojnih možnosti. Gre za spreminjanje projekcij v zahteve po prostoru in zahteve po opremljenosti prostora.

Analiza prostorskih razvojnih možnosti kaže, da bodo v prihodnosti pomembneje sooblikovali prostorski razvoj Slovenije predvsem vpetost Slovenije v globalni, evropski, medregionalni in regionalni gospodarski prostor ter sodobna informacijska družba. S temi pojavi so neposredno in posredno povezani tudi oblikovanje evroregij, spreminjanje pomena prostora kot lokacijskega dejavnika, migracije in spremembe $\mathrm{v}$ gospodarski in socialni strukturi prebivalstva, evropski standardi in merila, nova komunikacijska tehnologija prometa in zvez ter povečana skrb za varstvo okolja. (Černe, 2001)

Pričakovati je nadaljevanje in stopnjevanje sedanjih razvojnih teženj, ki se kažejo tudi v spreminjanju Slovenije v tranzitno ozemlje, v povečevanju koncentracije, centralizacije, depopulacije, regionalnih razlik ter učinkov, ki bodo vplivali na območja zgoščevanja, obmejna območja in območja strukturnega zaostajanja.

Slovenija želi s prostorskim razvojem na svojem ozemlju, na podlagi načel trajnostnega razvoja (s spoštovanjem, samonadzorom, zmernostjo in harmonizacijo razvoja) prispevati k pestremu, kakovostnejšemu in polnemu življenju prebivalcev ter h kakovosti fizičnega okolja v vsakem kraju in regiji. S tem želi ustvarjati primerne prostorske razmere in pogoje za posameznika, skupnosti in dejavnosti zaradi uresničevanja različnih razvojnih možnosti. Na tej podlagi se želi tudi aktivneje vključevati v mednarodne, meddržavne in medregionalne razvojne procese tako na ravni meddržavnega kot na ravni medregionalnega sodelovanja.

Iz pregleda prostorskih razvojnih možnosti bi lahko sklepali, da ima Slovenija ugodne prostorske razvojne možnosti v njenem geostrateškem položaju in izjemno pestri pokrajinski raznolikosti in raznovrstnosti, ki se kaže med drugim tudi v stikanju in prepletanju evropskih naravnih, kulturnih in gospodarskih enot. Nadalje v prepletanju različnih funkcij ter urbanih in podeželskih struktur znotraj in med omenjenimi enotami, ter nenazadnje v prostorski in funkcionalni členitvi v manjše razmeroma zaključene prostorske enote.

Omenjena dejstva so lahko temeljnega pomena za preseganje toge, okorne prostorske stvarnosti, in s tem za preprečevanje oziroma premagovanje prostorske homogenosti in monotonosti (standardiziranosti oziroma normativne urejenosti pokrajine, naselij in krajev). Ravno homogena prostorska struktura (množična kultura) briše vse omenjene značilnosti in ustvarja razmere, v katerih ni dovolj možnosti, da bi prihajale do izraza posebnosti in individualnosti, in kjer ni dovolj potrebnih pogojev za razvoj bogatih medsebojnih človeških odnosov. 
Omenjena prostorska struktura daje Sloveniji dovolj možnosti za to, da nobena njena pokrajina, kraj, in naselje ni navadna, nezanimiva. Vsak lahko s svojimi lastnimi potenciali, $\mathrm{v}$ medsebojni povezanosti in soodvisnoti $\mathrm{z}$ drugimi prispeva $\mathrm{k}$ temeljnim razvojnim pogojem, saj lahko številne raznolike in raznovrstne pokrajine razvijajo svojo polno moč skozi različne prostorske oblike, funkcije in strukture, ki pa se morajo razvijati v prostorski vzajemni soodvisnosti, s povezovanjem in dopolnjevanjem.

Slovenija ima torej razmeroma ugodne možnosti za ustvarjanje raznovrstnih prostorskih oblik, funkcij in struktur ter take rabe zemljišč, ki omogoča prebivalcem, da so v različnih pokrajinah, krajih in naseljih zaradi različnih namenov, v različnem času, a hkrati uporabljajo številne skupne zmogljivosti in storitve.

Ravno te omenjene značilnosti dajejo veliko možnosti, da so različne oblike, funkcije in strukture $\mathrm{v}$ določenih prostorskih razmerjih, da so skupaj, druga ob drugi v urbani in podeželski pokrajini, in sicer z možnostjo sobivanja različnosti, in ne nazadnje tudi nasprotij.

Omenjene prostorske razvojne možnosti so brez dvoma temeljnega pomena za spodbujanje pestrega, kakovostnega in polnega življenja v vsakem kraju in v vsaki regiji. Zato ima Slovenija ugodne prostorske razvojne možnosti za ustvarjanje take prostorske strukture, ki omogoča smotrno prostorsko razporeditev poselitvenih območij (stanovanj), delovnih mest in infrastrukture, in sicer v takem prostorskem vzorcu, ki bo kar v največji možni meri varoval odprti prostor. Prostorski razvoj usmerjan v razvojna območja, ki tvorijo privlačne urbane skupnosti različnih velikosti, in ki so ustrezno prostorsko razmeščene zagotavljajo zadosti prostora $\mathrm{v}$ vseh regijah za kakršne koli nadaljnje potrebe in razvoj, in to ob dejstvu, da ostaja večji del prostora odprt prostor. Slovenija želi ohranjati odprti prostor kot integralni del pokrajine (prostorske strukture)

Iz analize prostorskih razvojnih možnostih (Černe, 2001) bi lahko sklepali, da se prostorski razvojni potenciali kažejo predvsem v:

- umeščanju Slovenije v širše evropske regije oziroma v njeni pripadnosti in prisotnosti v alpskih, sredozemskih, srednje evropskih in podonavskih regionalizacijah ter zgodovinski in kulturni pripadnosti Srednji Evropi;

- izkoriščanju prednosti slovenskega ozemlja in znotraj tega vseh primerjalnih prednostih prostora, ki se nanašajo zlasti na prometno lego in vozlišča, naravne lepote za turistični razvoj, raznolikost krajin, vodno bogastvo itd. oziroma izkoriščanju vseh tistih mednarodnih usmeritev, ki so v našo korist in v zadržanosti do tistih, ki nam škodujejo;

- odprtosti, prehodnosti in povezanosti prostorske strukture $\mathrm{v}$ širše prostorske integracije;

- funkcionalnem povezovanju z območji, ki jih naseljuje slovensko manjšinsko prebivalstvo v sosednjih državah;

- povečani vlogi prostorskega planiranja kot dejavnosti zaradi usklajevanja različnih, pogosto nasprotujočih si interesov v prostoru, in sicer tudi z namenom ohranjanja vrednot krajin kot gospodarskega, naravnega in bivalnega okolja;

- uveljavljanju celostnega načrtovanja in gospodarjenja s sistemi ter celostnega varstva vrednot zaradi ohranitve splošnih prostorskih vrednot kot temeljnega izhodišča za prostorski razvoj na vseh ravneh; 
- krepitvi pravnega reda, izvajalskih implementov, informiranosti in participacije prebivalstva ter vzdrževanju celotnega sistema prostorske informatike;

- stopenjskemu pristopu in stopenjski hierarhiji dokumentov ter tesni medresorski povezavi in konsenzih na najvišji ravni;

- večjem sodelovanju sektorjev predvsem pri opredeljevanju tistih vsebin, ki so ključnega pomena za opredeljevanje razvojnih možnosti dejavnosti;

- korigiranju različnih razvojnih potencialov z omejitvami, ki izhajajo iz zahtev po ohranjanju stanja in kakovosti naravnega vira oziroma $\mathrm{v}$ aktivnem usmerjanju (spodbujanju) in omejevanju rabe zaradi prekrivanja interesov razvoja in varstva;

- opredeljevanju in varovanju razvojnih potencialov, usmeritvah za razvoj ter omejitev zaradi varstva virov, okolja in krajine;

- usklajevanju zahtev dejavnosti pri rabi naravnih virov in drugih rabah tako v procesu načrtovanja kakor tudi pri iskanju možnosti razvoja in rabe (sanacije) opuščenih območij izkoriščanja;

- zagotavljanju ustreznih potencialnih lokacij, ki bodo usklajene na regijski ravni in bodo presegale interese posameznih lokalnih skupnosti, poenostavitvi postopkov pridobivanja dovoljenj, skrajševanju časa za pridobivanje dovoljenj, v urejeni zemljiški knjigi in urejenem trgu nepremičnin;

- čimprejšnji uveljavitvi pokrajin kot podlage za učinkovito prostorsko in regionalno planiranje in celovitega izvajanja regionalne strukturne politike;

- optimalnemu trajnostno zasnovanemu prostorskemu načrtovanju poselitve, infrastrukture in pokrajinske rabe ter trajnemu prilagajanju zmogljivostim okolja in naravnih virov s prostorsko razmestitvijo in s tem okoljskih pritiskov in pokrajinske rabe.

Omenjene prostorske razvojne možnosti so predpogoj za razmišljanja o sprejemanju odločitev o oblikovni, funkcijski in strukturni zasnovi prostorskega razvoja oziroma prostorskih razmerij med posameznimi prostorskimi kategorijami in funkcijami. Odprte so za številne različne opcije, ki so lahko predmet sprejemanja odločitev v drugačnih pogojih in razmerah, v okviru drugačnih pomenov, mnenj in vrednot. Prostorske razvojne možnosti ustvarjajo podlago za oblikovanje konsenza, nakazujejo možne usmeritve, spodbujajo, dopuščajo spremembe in so prilagodljive, dopuščajo razpravo in niso v naprej sprejete odločitve. Prostorske razvojne možnosti še niso ključne odločitve, so pa podlaga za njihovo sprejemanje, saj niso v celoti, popolnoma eksplicitne.

Temeljna načela za preverjanje prostorskih razvojnih možnosti se nanašajo na suverenost odločanja, trajnostni in endogeni razvoj, splošne družbene vrednote, decentralizacijo in participacijo pod enakimi pogoji na različnih ravneh odločanja, znanstveni in strokovni pristop ter na spoštovanje mednarodnih meddržavnih ter regionalnih pogodb in dogovorov. Splošni cilji prostorskega razvoja pa so naravnani na izboljšanje kakovosti življenja in fizičnega okolja, zagotavljanje trajnostnega razvoja in razvojnih priložnosti in pogojev za vse prebivalce.

V kolikor ne želimo, da se prostorski razvoj še nadalje izraža $v$ takih pojavih, procesih in oblikah, (strukturah in funkcijah) kot do sedaj, potem moramo vplivati na razmere v katerih nastajajo ti pojavi in procesi oziroma moramo odpravljati vzroke za njihov nastanek. 
Gre za vprašanje stopnje prilagajanja prostorskih razvojnih možnosti različnim gospodarskim in družbenim pogojem ter nekaterim prostorskim parametrom procesa razvoja. Do kakšne mere upoštevati te pogoje oziroma do kakšne mere jih spreminjati zaradi doseganja zaželenih ciljev prostorskega razvoja? Gre tudi za vprašanja, ali sploh želimo take prostorske razvojne možnosti, ali imamo ugodne pogoje za uresničevanje prostorskih razvojnih možnosti, ali smo sposobni ustvarjati dodatne, nujno potrebne predpogoje za uresničevanje določenih prostorskih razvojnih možnosti, in ne nazadnje, katere predpogoje moramo zagotoviti, da bomo lahko uresničevani določene razvojne možnosti? Ali naj ustvarjamo take prostorske strukture s katerimi bomo dobro služili (čim več zaslužili, dobro tržili) ali take prostorske strukture s katerimi bomo imeli čim manj stroškov (bomo čim več prihranili energije, denarja, prostora, narave itd.) ali take prostorske strukture, kjer se bomo prijetno počutili in zdravo živeli.

Prostorske razvojne možnosti na področju uresničevanja različnih javnih, zasebnih in sektorskih razvojnih pobud se kažejo npr. v jasnih opredelitvah območij, kjer bo država sama ali v obliki partnerstva prednostno spodbujala, delno omejevala (določala pogoje) in na nekaterih območjih celo prepovedovala uresničevanje razvojnih pobud. Pri uravnoteženosti javnega in zasebnega sektorja, kjer je zasebna lastnina, lastnina vsakega posameznika, naj vsak posameznik z urejanjem svoje lastnine prispeva $\mathrm{k}$ skupni podobi, funkciji in strukturi prostora/pokrajine. Vsaka posamezna hiša, vsak posamezni poseg v prostor naj bo del celote, del celotne prostorske strukture, in naj prispeva $\mathrm{k}$ celoviti prostorski strukturi $\mathrm{z}$ različnih vidikov.

Prostorske razvojne možnosti moramo zato soočiti s:

- $\quad$ prihodnostjo, zato pogojev, potencialov in omejitev ne moremo ocenjevati samo v luči standardov in normativov, ki izhajajo iz sedanjih razmer;

- $\quad$ kumulativnimi učinki številnih, pogosto nekoordiniranih odločitev, katerih vidni rezultati in posledice so zaznavne šele po preteku relativno daljšega obdobja, zato prostor ne prenese improvizacij, poskusov, marveč zahteva premišljeno in odgovorno ravnanje;

- odgovornostjo do prostora, ki je primarna odgovornost oziroma mora biti brezpogojna, torej neodvisna od človekovih interesov;

- zadovoljevanjem lastnih potreb in želja v razmerju do prostora in okolja, ki imata končno sposobnost nameščanja rasti, saj sta naravno omejeni dobrini;

- $\quad$ obstojem različnih ravni prostorske strukture kot enkratne strukture, ki je odvisna od lokalnih in regionalnih pogojev in razmer;

- omejenim fizičnim nadzorom nad prostorskim razvojem;

- $\quad$ spontanim in/ali načrtovanim prostorskim razvojem oziroma pasivnim in/ali aktivnim odnosom do razvoja;

- $\quad$ različnimi prostorskimi, družbenimi, gospodarskimi, socialnimi in institucionalnimi ter ostalimi razmerami in njihovimi spremembami;

- neenovitim sistemom sektorskega, strateškega, razvojnega, regionalnega in prostorskega planiranja;

- $\quad$ usklajevanjem številnih in različnih ciljev, interesov, potreb in želja sektorjev in posameznikov, in sicer na podlagi zagotavljanja materialnih pogojev (zemljišč in infrastrukture) ter ustvarjanja primernega ravnotežja med potrebami po razvoju in interesi varovanja; 
- zasebnim podjetništvom in sodobnim konkurenčnim tržiščem ter individualnim razvojem;

- in ne nazadnje, tudi časom, ki je potreben za reševanje sedanjih prostorskih problemov.

Zato je potrebno prostorske razvojne možnosti opredeljevati znotraj konteksta:

- gospodarskega razvoja, družbene pravičnosti in varstva okolja;

- sistema strateškega planiranja;

- sistema družbenih sprememb zasebnega podjetništva in sodobnega konkurenčnega tržišča;

- razvojnega planiranja oziroma pripravljanja različnih dokumentov na državni, regionalni in lokalni ravni.

- tržne in družbene racionalnosti oziroma učinkovitosti;

- ustrezne oziroma primerne rabe skupnega človekovega vira;

- brezpogojnega upoštevanja človeških in okoljskih stroškov rasti;

- načrtovanega razvoja.

Pogoji, potenciali in omejitve za prostorske razvojne možnosti se nanašajo na cilje prostorskega razvoja in ključne prostorske probleme Slovenije, ki določajo obstoječe razmere in želene razmere $\mathrm{v}$ katerih oziroma s katerimi bo potekal nadaljni prostorski razvoj.

Razvojne težnje in splošna spoznanja o splošnih in prostorskih pogojih ter omejenosti naravnih potencialov narekujejo Sloveniji trajnosten in celovit uravnotežen prostorski razvoj na vseh ravneh. Zato mora načrtovanje prostorskega razvoja in s tem tudi reševanje številnih neugodnih prostorskih razmerij in nakopičenih problemov ter nekaterih nezaželenih pojavov in procesov prispevati $\mathrm{k}$ soustvarjanju:

- kompleksnega, raznovrstnega, raznolikega, večpomenskega prostora in življenja;

- varnih, udobnih in zdravih življenjskih razmer ter

- prostora, ki je usklajen s fizičnimi, naravnimi in okoljskimi strukturami in procesi. (Černe, Kušar, 2002)

Gre torej za kakovost življenja, kakovost fizičnega okolja, trajnostni razvoj, razvojne priložnosti in pogoje za vse. To pa pomeni uresničevanje naslednjih splošnih ciljev načrtovanja (urejanja) prostorskega razvoja:

- ustvarjati take prostorske strukture, ki omogoča prijetno bivanje in življenje ter izboljšujejo okoljske pogoje življenja;

- zagotavljati prostorske integracije države in ohranjanje nacionalne prostorske identitete ter ustrezne vpetosti v prostorske in regionalne razsežnosti Evrope;

- dosegati skladnejši prostorski razvoj na medregionalni in regionalni ravni;

- dosegati prostorsko - lokacijske učinkovitost, varčne rabe zemljišč in sredstev, vloženih v zemljišča, ter energetsko varčnost prostorskih rešitev;

- dosegati enakomernejši, prostorsko uravnotežen razvoj poselitvenega omrežja in uravnoteženo koncentriran in prostorsko zaokrožen razvoj naselij v poselitvenem omrežju;

- dosegati enakomernejši in prostorsko uravnotežen razvoj prometnih omrežij ter ugodnejša razmerja med javnimi in zasebnimi oblikami prevoza; 
- ohranjati potenciale (ekološke, naravne, estetske, funkcionalne) vseh naravnih in ustvarjenih vrednot krajine in njenih posameznih sestavin;

- izboljšati izobraževanje in osveščanje javnosti na področju prostorskega razvoja.

Sodobne spremembe, osamosvojitev, suverenost, tržno gospodarstvo, zasebna lastnina, politični sistem parlamentarne demokracije, lokalna samouprava in vključevanje v evropske integracije ter $\mathrm{v}$ globalni gospodarski, komunikacijski, kulturni in naravni prostor ter njihove prostorske posledice zahtevajo odgovorno in učinkovito načrtovanje prostorskega razvoja. Slovenija mora ob upoštevanju skupnih mednarodno in evropsko opredeljenih načel prostorskega razvoja suvereno odločati o lastnem prostoru zato, da bi zagotovila trajno uravnotežen razvoj in reševala posamezne slabosti spontanega in enostranskega razvoja. Učinkovit in skladen prostorski razvoj je treba oblikovati na zavestnem spodbujanju, usmerjanju in regulaciji razvoja znotraj sprejetih izhodiščih in dogovorjenih ciljev.

Zato so možni cilji prostorskega razvoja predvsem:

- ustvarjati tako prostorsko strukturo, ki bo kar v največji meri prispevala k prostorski, okoljski in funkcionalni raznolikosti, medsebojni povezanosti, vzajemni soodvisnosti in dopolnjevanju vseh območij ter k skladnejšemu regionalnemu razvoju;

- doseči medsebojno sodelovanje mest, urbanih območij in podeželja (odprtega prostora) ob istočasnem varovanju narave, naravnih virov in ustvarjenih vrednot prostora;

- s prostorsko razporeditvijo poselitvenih območij, delovnih mest in infrastrukture ter aktivnim spodbujanjem razvoja želi zagotavljati dovolj prostora za razvoj v vseh regijah ob kar največji možni meri varovanja odprtega prostora;

- ohranjati in razvijati ekološke, naravne, estetske in funkcionalne potenciale ter varovati in razvijati kulturno krajino, varovati urbanistično in arhitekturno dediščino ter vse naravne in ustvarjene vrednote prostora in njegove posamezne sestavne dele;

- dosegati dolgoročno racionalnejšo rabo prostorskih potencialov, varčno rabo zemljišč in sredstev vloženih v zemljišča ter energetsko varčnost prostorskih rešitev, preprečevati potratno rabo zemljišč, povečevanje dnevne migracije, prometnih obremenitev, višjih stroškov oskrbe in storitev, stratifikacije prebivalstva ter brezobličnih poselitvenih območij;

- preprečevati razpršeno (decentralizirano) obliko prostorskega razvoja zaradi potratne rabe zemljišč, povečevanja dnevne migracije, prometnih obremenitev, višjih stroškov oskrbe in storitev, stratifikacije prebivalstva ter brezobličnih poselitvenih območij v obliki širjenja hiš vzdolž prometnega omrežja, kjer je vsak stavba sama za sebe, brez kakršnega koli razmerij do ostalih struktur;

- zagotavljati prostorske razvojne možnosti za zasnovo prometnega sistema, ki bo odgovarjal oziroma sovpadal z razpršenim vzorcem poselitve in rabe zemljišč so razmeroma zelo slabe;

- obvladovati prostorsko širjenje razvoja oziroma imeti blag nadzor nad novim razvojem s čim manjšim »odpiranjem《 novih zemljišč za razvoj in hkrati omogočanjem intenzivnejšega razvoja znotraj obstoječih površin;

- zmanjševati stopnje tistih prostorskih sprememb, ki zahtevajo obsežno odpiranje čisto novih zemljiščih za razvoj; 
- $\quad$ izvajati rehabilitacijo, reciklažo in sanacijo obstoječih struktur (razvrednotena mestna in primestna območja, podeželska ravninska območja intenzivnega kmetijstva, hidromelioracij, kraška gorska območja intenzivnega turizma in rekreacije, obalno območje), kar lahko prispeva k povečevanju, vsaj do neke mere prostorskih razvojnih možnosti znotraj razvojnih območij;

- zagotavljati nepotratno rabo površin zaradi zagotavljanja enega izmed pomembnih elementov trajno uravnoteženega prostorskega razvoja in možnosti za učinkovito ter dolgoročno racionalno rabo prostora.

\section{PRIMERJALNA ANALIZA PROSTORSKIH RAZVOJNIH MOŽNOSTI}

Primerjalna analiza prostorskih razvojnih možnosti je narejena na podlagi analize:

- $\quad$ ciljev na področju prostorskega razvoja, razvoja poselitve, infrastrukture, krajine, regionalnega razvoja in okoljskih vidikov razvoja ter prostorskih ciljev na področju posameznih sektorjev;

- $\quad$ vizij, možnih konceptov, scenarijev, modelov, planskih območij, nacionalnih strategij in programov in usmeritev sektorjev pri zadovoljevanju lastnih razvojnih potreb;

- $\quad$ predlaganih možnih oblik in struktur prostorskega razvoja ter njihovih funkcij;

- $\quad$ prostorskih pogojev, potencialov, omejitev in razmer ter posameznih prostorskih kategorij;

- $\quad$ vsebinske skladnosti med različnimi prostorskimi možnostmi.

Preglednica 1: Načini prikazovanja prostorskih razvojnih možnosti

Table 1: Methods for presentation of spatial development alternatives

\begin{tabular}{|l|c|c|c|c|c|}
\hline & scenariji & koncepti & modeli & potenciali & strategije \\
\hline Med.vidik & & & & & \\
\hline gospodar. & $\mathrm{x}$ & & & $\mathrm{x}$ & $\mathrm{x}$ \\
\hline družba & $\mathrm{x}$ & & & & \\
\hline prostorski razvoj & $\mathrm{x}$ & & & & \\
\hline poselitev & $\mathrm{x}$ & $\mathrm{x}$ & & & \\
\hline infrastruk. & $\mathrm{x}$ & $\mathrm{x}$ & & & \\
\hline krajina & & $\mathrm{x}$ & $\mathrm{x}$ & $\mathrm{x}$ & \\
\hline reg.raz. & & $\mathrm{x}$ & & & $\mathrm{x}$ \\
\hline okoljski vidik & & & & & $\mathrm{x}$ \\
\hline sektorji & & & & & \\
\hline kmetijstvo & & & & & \\
\hline gozdar. & & $\mathrm{x}$ & & & \\
\hline Vod.gos. & & $\mathrm{x}$ & & & \\
\hline rudarstvo & & & & & \\
\hline energetika & & & & & \\
\hline
\end{tabular}


Na podlagi omenjenih analiz je zasnovano opredeljevanje skupnih elementov prostorskih razvojnih možnosti. Sama ocena prostorskih razvojnih možnosti pa je podana na podlagi soočanja prostorskih razvojnih možnosti s:

- $\quad$ ključnimi prostorskimi razvojnimi problemi;

- temeljnimi predpostavkami in predvidevanji o prihodnjem prostorskem razvoju;

- $\quad$ prostorskimi pogoji, potenciali in omejitvami za prostorski razvoj;

- cilji na področju prostorskega razvoja, poselitve, infrastrukture, krajine in regionalnega razvoja ter okoljskega vidika razvoja.

Preglednica 2: Primerjava prostorskih razvojnih možnosti na podlagi scenarijev

Table 2: Comparison of scenarios for spatial development alternatives

\begin{tabular}{|c|c|c|c|}
\hline Gospodarstvo & prostorski razvoj & poselitev & infrastruktura \\
\hline $\begin{array}{l}\text { - hitra } \\
\text { vključitev } \\
\text { v EU; } \\
\text { - odložena } \\
\text { vključitev } \\
\text { v EU. }\end{array}$ & $\begin{array}{l}\text { - } \text { spontani:; } \\
\text { - gospodarsko- tehnološki } \\
\text { - optimalni ali želeni; } \\
\text { - } \text { konzervativni; } \\
\text { - periferna fragmentacija; } \\
\text { - } \text { spontani razvoj s parci- } \\
\text { alnimi korektivnimi } \\
\text { ukrepi; } \\
\text { - } \text { pomembno odstopanje od } \\
\text { ekstrapolacij sedan-jih } \\
\text { spontanih teženj. }\end{array}$ & $\begin{array}{l}\text { - } \text { spontani; } \\
\text { - dezurbani-zacija; } \\
\text { - } \text { razvojne osi; } \\
\text { - utrditev "policent. urbanega } \\
\text { - } \text { sistema". } \\
\text { - } \text { razpršen razvoj; } \\
\text { - policentrični razvoj; } \\
\text { - oblikovanje razvojnih osi (pospe- } \\
\text { šena tehnološka moder.); } \\
\text { - decentral. zgostitvena poselitev: } \\
\text { - dekoncentrirano zgoščevanje } \\
\text { poselitve: manjši zgostitveni cen- } \\
\text { tri na sububan. } \\
\text { - podeželskih območjih. }\end{array}$ & $\begin{array}{l}\text { - spontani; } \\
\text { - aktivni; } \\
\text { - idealni. }\end{array}$ \\
\hline
\end{tabular}

Preglednica 3: Primerjava prostorskih razvojnih možnosti na podlagi konceptov

Table 3: Comparison of concepts for spatial development alternatives

\begin{tabular}{|c|c|c|c|c|}
\hline poselitev & $\begin{array}{l}\text { poselitev: občasna } \\
\text { bivališča }\end{array}$ & infrastruktura & krajina & regionalni razvoj \\
\hline $\begin{array}{l}\text { - } \text { nepolar. } \\
\text { (spontan); } \\
\text { - } \text { polar. } \\
\text { (usmerjen); } \\
\text { - na podeželju: } \\
\text { - } \text { regionalistični; } \\
\text { - univerzalistični. }\end{array}$ & $\begin{array}{l}\text { - vzvod ohranja- } \\
\text { nja poseljenosti } \\
\text { in varovanja } \\
\text { kulturne } \\
\text { krajine; } \\
\text { - potencial za } \\
\text { razvoj turizma; } \\
\text { - element narodne } \\
\text { identitete. }\end{array}$ & $\begin{array}{l}\text { - } \text { primarni; } \\
\text { - sekundarni; } \\
\text { - terciarni. }\end{array}$ & $\begin{array}{l}\text { - } \text { pred. razvojni; } \\
\text { - } \text { pred. varovalni; } \\
\text { - } \text { razvojno-varovalni. } \\
\text { prednostno varstvo } \\
\text { vrednot in mini- } \\
\text { malni razvoj; } \\
\text { - prednostni razvoj } \\
\text { ter minimalno } \\
\text { varstvo vrednot; } \\
\text { - srednja stopnja } \\
\text { varstva in razvoja. }\end{array}$ & $\begin{array}{l}\text { - } \text { koncept } \\
\text { sedanjega } \\
\text { odzivanja; } \\
\text { - koncept } \\
\text { zaželenega } \\
\text { odzivanja; } \\
\text { - koncept } \\
\text { uresničljivega } \\
\text { odzivanja. }\end{array}$ \\
\hline
\end{tabular}

Prostorske razvojne možnosti so bile nakazane v obliki scenarijev, konceptov, modelov, planskih kategorij in strategij razvoja. Iz preglednice Načini prikazovanja prostorskih raz- 
vojnih možnosti je razvidno, da so bila prostorske razvojne možnosti najpogosteje nakazane v obliki konceptov in scenarijev, v najmanjši meri z modeli, potenciali, in strategijami.

Zaradi razmeroma raznolikega metodološkega prikazovanja prostorskih razvojnih možnosti, njihovega vsebinskega opredeljevanja ter različnega števila njihovih možnih različic prikazujemo primerjalne analize samo za scenarije in koncepte.

Iz analize je razvidno, da so prostorske razvojne možnosti opredeljene v dveh temeljnih kategorijah: v oblikovanju splošnih prostorskih struktur razvoja in v oblikovanju določenih razmerij med razvojnimi in varovalnimi interesi. Razmerja med razvojnimi prizadevanji in varstvenimi vidiki prostorskega razvoja se izražajo v razvojnih in varovalnih (varstvenih) funkcijah, in sicer ne toliko v smislu dveh nasprotnih skrajnosti, marveč v smislu različnih medsebojnih stopenj prepletanja funkcij prostora:

- $\quad$ prednostno razvojni;

- $\quad$ prednostno varovalni;

- razvojno varovalni;

- $\quad$ sektorski;

- razvojno-varstveni;

- varstveni;

- $\quad$ razvoj minimalnega upoštevanja okoljskih omejitev;

- $\quad$ razvoj maksimalnega ohranjanja in zavarovanja (po)krajinske in biotske raznovrstnosti;

- optimalno sonaravno zasnovan prostorski razvoj.

\section{OCENA PROSTORSKIH RAZVOJNIH MOŽNOSTI}

Analiza jasno kaže, da so v ospredju prostorskega razvoja tisti pojavi in procesi, ki imajo v prvi vrasti več ali manj negativni predznak. Sedanji pogoji za uresničevanje prostorskih razvojnih možnosti, ki pa imajo več ali manj pozitivni predznak pa se nanašajo na posamezne razmere, pojave in procese na področju mednarodnega vidika, poselitve, krajine in okoljskega vidika. Za vse ostale pogoje pa lahko rečemo, da so takšni, ki imajo negativni predznak. Iz ocene izhaja, da imamo samo na področju prostorskega razvoja opravka $\mathrm{s}$ skoraj dvajsetimi negativnimi prostorskimi razmerami, ki pomembneje vplivajo na nastajanje prostorskih problemov. (Černe, Kušar, 2002) Tudi analiza teženj, predpostavk, predvidevanj in pričakovanj kaže na prostorske razvojne možnosti v negativni luči. Težnje, predpostavke, predvidevanja in pričakovanja na področju prostorskega razvoja kažejo torej na to, da v prihodnosti ni pričakovati večjih odstopanj od sedanjih teženj. Številni procesi in pojavi prostorskega razvoja na različnih področjih, ki imajo več ali manj negativen predznak se naj bi namreč nadaljevali tudi v prihodnosti:

- $\quad$ ekonomski in socialni problemi bodo naraščali;

- $\quad$ na podeželju se bo upadanje števila prebivalstva še nadaljevalo;

- depopulacija v odmaknjenih, pretežno ruralnih, gorskih, hribovskih in kraških predelih,

- $\quad$ nadaljnje tuje poseljevanj nekaterih naših krajin;

- $\quad$ pritisk modernih industrijskih in obrtnih obratov na še proste kmetijske površine;

- urbanizirana območja bodo še nadalje podvržena povečanim zahtevam po novih stanovanjskih, proizvodnih in obrtnih površinah; 
- neprestani in vedno ostrejši konflikti med kmetijsko rabo in urbano rabo zemljišč;

- težnje po opuščanju kmetijskih dejavnosti; nadaljnje zaraščanje in zmanjševanje kmetijskih zemljišč

- nevarnost porušitve raznolike in pestre strukture slovenskega podeželja, uničenja slikovitosti kulturne krajine ter ekološkega razvrednotennja in ravnovesja;

- poglabljale se bodo intraregionalne gospodarske disparitete;

- nadaljnje povečevanje razlik med regijami, predvsem v gospodarski razvitosti.

- obremenitve okolja bodo naraščale skupaj z naraščanjem prometa itd..

- vrednote ljudi v odnosu do prostora imajo vse značilnosti socialno-prostorske ozkosti ali sebičnosti itd.

Če soočimo težnje, predpostavke, predvidevanja in pričakovanja še z razmeroma neugodnimi sedanjimi prostorskimi pogoji, znotraj katerih poteka prostorski razvoj (velike razlike $\mathrm{v}$ prostorskem razvoju regij, neenakomeren urbani razvoj, pritisk suburbanizacije ob avtocestnem križu, stihijska in nenadzorovana razpršena gradnja, velik delež nelegalnih oziroma tako imenovanih črnih gradenj, degradirana urbana in druga območja, propadanje starih industrijskih mest, nenačrtna in pomanjkljiva prenova mestnih jeder, slaba infrastrukturna opremljenost naselij, nerešena vprašanja ravnanja z odpadki, prestrukturiranje podeželskega prostora, obsežno zaraščanje kmetijskih zemljǐč, slabe prometne povezave ob sicer razvejanem cestnem omrežju, premajhen poudarek železniškega prometa in nezadostna mreža javnega prevoza, slaba sistemska rešitev varstva kmetijskih zemljišč, nespoštovanje in neupoštevanje predpisov urejanja prostora, pomanjkanje regionalne ravni, pomanjkanje ustreznih kadrov, nepovezano sodelovanje sektorjev), potem realno ne moremo pričakovati pomembnejših premikov, sprememb oziroma preusmeritev v krajšem oziroma srednjeročnem časovnem obdobju. Doseganje idealnih oziroma zahtevnih in raznovrstnih ciljev prostorskega razvoja, je ob razmeroma neugodnih pogojih in hkrati razmeroma neugodnih težnjah, predpostavkah, predvidevanjih in pričakovanjih izredno težko uresničevati. Zato bodo potrebni dolgoročni napori za spreminjanje obstoječih prostorskih pogojev oziroma za soočanje z neugodnimi razvojnimi težnjami, predpostavkami, predvidevanji in pričakovanji glede prihodnjega prostorskega razvoja.

Omenjeno spoznanje lahko pomeni sprejemanje odločitev o aktivnejšemu poseganju v nekatere prostorsko razvojne procese zaradi odpravljanja vzrokov za njihovo nastajanje oziroma zaradi njihovega spreminjanja, preoblikovanja, usmerjanja ali celo preprečevanja. Aktivnejše sodelovanje $\mathrm{v}$ razvojnem procesu mora biti vsekakor zasnovano na postopnem selektivnem pristopu, in sicer tako na področju reševanja posameznih prostorskih problemov, ki jih povzročajo sedanji pogoji oziroma težnje, predpostavke, predvidevanja in pričakovanja, kot na področju vzpostavljanja pravno-formalnih in institucionalnih okvirjev za njihovo reševanje. To pa zahteva jasno opredelitev prednostnih nalog na področju usmerjanja in spreminjanja nekaterih pojavov in procesov prostorskega razvoja, $v$ okviru splošnih dolgoročnih ciljev prostorskega razvoja, opredelitev konkretnih ciljev za njihovo reševanje, in ne nazadnje opredelitev načinov za aktivno poseganje $\mathrm{v}$ razvojni proces na različnih področjih in območjih. 
Ravno zaradi omenjenega velikega razkoraka med zastavljenimi dolgoročnimi cilji prostorskega razvoja in razmeroma neugodnimi pogoji, težnjami, predpostavkami, predvidevanji in pričakovanji je smiselno razmišljati o tistih prostorskih razvojnih možnostih, ki omogočajo stalno prisotnost in zmerno stopnjo poseganja v prostorske razvojne procese, z namenom dolgoročnega reševanja razvojnih vprašanj znotraj sprejemljivih in dogovorjenih ciljev prostorskega razvoja. Take prostorske razvojne možnosti lahko nudijo tudi veliko stopnjo odprtosti za nastajanje in ustvarjanje različnih razvojnih pobud. S tega vidika so prostorske razvojne možnosti na nek način tudi v skladu s sektorskimi usmeritvami, ki so zasnovane na podlagi hkratnega poudarjanja razvojne in varovalne komponente njihovega razvoja in uresničevanja njihovih potreb, oziroma vidijo njihove razvojne možnosti v določenih stopnjah medsebojnega usklajevanja razvojnih in varstvenih vidikov. S tega vidika lahko govorimo tudi o določeni meri stopnje usklajenosti med različnimi prostorskimi razvojnimi možnostmi oziroma o nekaterih elementih za zasnovo skupnih temeljev prostorske strategije.

$\mathrm{Na}$ tej podlagi ocenjujemo, da se realne prostorske razvojne možnosti kažejo v prvi vrasti znotraj naslednjih razvojnih konceptov in scenarijev:

gospodarstvo in družba: $\quad$ scenarij hitre vključitve v EU;

prostorski razvoj: $\quad$ scenarij pomembnejšega odstopanja od ekstrapoloacije sedanjih spontanih prostorsko razvojnih teženj;

poselitev: policentrični scenarij (poselitev, stanovanja) oziroma polariziran (usmerjen) koncept (poselitev) ter koncept sekundarnih bivališč kot potencial za razvoj turizma in hkrati vzvod ohranjanja poseljenosti in varovanja kulturne krajine;

infrastruktura: aktivni scenarij;

krajina: razvojno varovalni koncept oziroma model srednje stopnje varstva in razvoja ter normativnega varstva oziroma vključevanja varstvenih ciljev $\mathrm{v}$ postopke načrtovanja (krajina: naravne in kulturne vrednote) in korigiranja potencialov $\mathrm{z}$ omejitvami, ki izhajajo iz: zahtev zaradi varstva voda, varstva gozdov, interesov razvoja turizma varstva narave in varstva kulturne krajine (krajina: kmetijstvo);

regionalni razvoj: $\quad$ koncept uresničljivega odzivanja oziroma strategija spodbujanje skladnejšega regionalnega razvoja;

okoljski vidik: optimalno sonaravno zasnovano prostorsko načrtovanje.

\section{PROSTORSKE VIZIJE}

Obstaja vedno večja stopnja kompleksnosti in medsebojne soodvisnosti in povezanosti vseh sestavin razvoja. Vprašanja odločanja na višjih ravneh so vedno bolj težavna, kar po pravilu povzroča širjenje časovnega obzorja, zato je racionalnost vse večjega števila odločitev možno meriti le dolgoročno. Seveda pa element časa istočasno tudi omejuje stopnjo racionalnosti odločitev. Edini razlog temu je neznanka, ki ji pravimo prihodnost. 
Samo na podlagi predstave, zamisli, se v zavesti pojavlja kategorija prihodnosti, saj je prihodnost tisto česar še ni. Kako torej prihodnost spoznati? Edini možni način je, da si jo zamišljamo, saj razvoja v prihodnosti človek ni zmožen v celoti spoznati. Prihodnost je torej področje možnega. Obstajajo vizije, pa čeprav v naših sanjah, ki v skrajnosti opredeljujejo naše odločitve. Naše želje usmerjajo in kažejo na povsem jasen način naše resnične vrednote. Planiranje je torej »umetnost možnega«, vendar samo v tistem pomenu, da lahko le prihodnost spreminjamo glede na naše potrebe in želje. Zgodovina je za razliko od možnosti znanost o »ne možnostih«, to je o tistem, kar je človek že naredil, a hkrati tudi o tistem, kar človek vse do sedaj še ni naredil oziroma mogel narediti. Samo preteklost in sedanjost torej lahko spoznavamo z določeno stopnjo zanesljivosti, nimamo pa moči, da bi jo spreminjali. »Geografija poskuša razlagati kakšen svet je, planiranje pa kakšen bi svet moral biti«. (Černe, 1999, 65) Na drugi strani pa imamo vse možnosti, da si zamišljamo prihodnost, ne moremo pa je v celoti spoznati. Nezanesljivost je torej temeljna značilnost prihodnosti. Razsežnost časa v smislu širjenja časovnega obzorja ima pri tem vedno večji pomen. $\mathrm{S}$ širjenjem časovnega obzorja se namreč zmanjšuje možnost ekzaktnega pristopa. Časovna razsežnost na nek način opredeljuje vsebino vizije. Intelektualni napori se premaknejo na področje združevanja dejstev in predpostavk v določen sistem.

Prvi korak pri opredeljevanju možnih rešitev omenjenih vprašanj je vsekakor v priznavanju, da ta vprašanja obstajajo. Drugi korak pa pomeni brez dvoma opredeljevanje njihovih premis.

Planerji vztrajajo na tem, da je planiranje sinteza, ki mora biti prežeta z vizijo. Lahko bi celo rekli, da vizije na nek način pomagajo planerjem pri opredeljevanju njihove lastne strokovne identitete. Planiranje brez vizij je verjetno zgolj reprodukcija.

Prostorske vizije so eden izmed možnih načinov za razmišljanja o prihodnosti. Gre za to, da drug drugemu povemo o čem razmišljamo predvsem pa tudi, kako razmišljamo o prihodnjem razvoju. Pri tem ne gre za to ali so pogledi resnični, pravilni, marveč zato, da jih soočamo z ostalimi vizijami, pa naj bodo to znanstvene, ekološke, arkadijske, holistične, ali poetske. Tako kot številni drugi strokovnjaki namreč, tudi prostorski planerji nimajo monopola nad področji njihovega dela. Njihove vizije tekmujejo z vizijami prebivalcev, investitorjev, potrošnikov, predstavnikov civilne družbe itd.

Naj navedemo le nekaj primerov različnih vizij, ki jih srečujemo v vsakdanji planerski praksi, nanašajo pa se več ali manj na planerske dokumente na ravni držav:

- $\quad$ imeti vizijo o prihodnjem razvoju, ki bo kar v najboljši meri uporabila vse možne vire« (Evropa 2000, 1991);

- $\quad$ dosegati večje fizične in ekonomske integracije zaradi razvijanja prostorske strukture, ki dosega visoke okoljske standarde, kaže koristi sodelovanja na področju prostorske politike in je sposobna ponuditi praktične smernice za integracijo in harmonizacijo prostorskih vidikov nacionalnih politik« (VASAB 2010, 1995);

- namišljeno pismo, ki ga v letu 2018 piše navdušen turist na Danskem oziroma »dinamično središče gospodarske prosperitete za Severno Evropo, ki se ponaša z okoljsko kakovostjo kot eno izmed njegovih mednarodnih prepoznavnosti« (Denmark 2018, 1997);

- »doseganje rasti, konkurenčnosti in decentralizacije gospodarstva z visoko stopnjo zaposlenosti za EU kot celoto, zagotovljanje gospodarske in socialne kohezije ter trajnosthe rasti« (Bela knjiga o rasti, konkurenci in zaposlenosti, 1993); 
- »okoljsko prijazna, konkurenčna in visoko tehnološko razvita država ter dežela mednarodnega ravnotežja (Finland 2017, 1995);

- $\quad$ kompleksen, raznovrsten, raznolik in večpomenski prostor ter življenje v njem, varne, udobne in zdrave življenjske razmere, ter prostor, ki je usklajen z lastnostmi fizičnih in naravnih struktur ter procesov« (Černe, Gulič, 1999).

Prostorske vizije uporabljamo torej za poglede v prihodnost. Pomenijo neke vrste oddaljen pogled, ki ga uporabljajo planerji, ko gledajo na svet in oddaljenost, ki je vsiljena planerjem zaradi obsežnosti predmeta, ki ga proučujejo. Prostorske vizije so namenjene torej odkrivanju, spoznavanju in razumevanju tistega kar še ne obstaja, tistega, kar naj bo šele ustvarjeno (Černe, 1999). Zato velja prostorske vizije razumeti tudi kot neko obliko zaželenih podob in možne prihodnosti. Dyson je uporabil metaforo o podobah v ogledalu za poglede v prihodnost: »Prihodnost je moje oddaljeno ogledalo. Ogledala uporabljam za nameščanje problemov in težav sedanjosti v širše perspektive« (Haggett, 1990, 3). Podoba je seveda retoričen pojem, najpogosteje opisana s kombinacijo besed, ki vzpodbujajo neke vrste asociacij. Zelo pogost tip takih podob so metafore, ki so navidezno-logični okvirji za asociacije. Okoli takih metafor so lahko zgrajena načela za »urejanje prostora«, ki na nek način simbolizirajo prostorska pravila in red. Uresničevanje teh načel pa zahteva opredelitev prostorskih planerskih načel, ki so podlaga za vsebinsko zasnovo prostorskih planov, njihovo pripravo in uresničevanje.

Prostorske vizije niso napovedi, vsekakor tudi ne vnaprejšnja odločitev o prihodnji prostorski strukturi, kaj šele o končni prostorski strukturi. Prostorske vizije se ne nanašajo na stalen prostorski red oziroma ohranjanje vseh pojavov in procesov znotraj stalnih prostorskih okvirjev. Gre za preseganje nekakšnega prostorskega determinizma in vračanje na raven spoznavanja razmerij in procesov prostorske strukture. Kljub temu pa prostorske vizije omogočajo opredeljevanje dolgoročnosti kot elementa relativne stabilnosti znotraj stalnih sprememb. Gre preprosto za sposobnost razmišljanja ali konceptualiziranja prostorske strukture kot celote. Pri tem pa bi rad poudaril, da so izkušnje o prostoru, v prostoru in s prostorom seveda preveč kompleksne, da bi jih lahko zaobsegli v eni sami viziji. Ravno zaradi te notranje pestrosti pogledov lahko prostorske vizije veliko prispevajo k širjenju našega spoznavanja prihodnosti. Prostorske vizije so neke vrste hiš s številnimi vrati, ki nudijo takšne ali drugačne poglede. Toda, tako kot je filozof William James zapisal v njegovi poletni hišici v Angliji, ta vrata so na splošno odprta navzven (Perry, 1948, 175). Skratka, prostorske vizije računajo na moč razprave, strokovne, javne in politične.

\section{INAČICE PROSTORSKIH RAZVOJNIH MOŽNOSTI}

Na podlagi vizij, prostorskega razvoja, celovite analize prostorskih razvojnih možnosti smo opredelili štiri inačice prostorskega razvoja: spontano inačico, inačico intenzivnega razvoja, intenzivno varstveno inačico in inačico trajnostnega razvoja, in sicer za poselitev, infrastrukturo, krajino, regionalni razvoj in okoljski vidik prostorskega razvoja. V nadaljnjem besedilu so opredeljene temeljne vsebine in elementi posameznih inačic prostorskih razvojnih možnosti. 


\section{SPONTANA INAČICA}

Sponatana inačica pomeni nadaljevanje dosedanjih - večinoma negativnih teženj v prostorskemu razvoju.

Na področju poselitvenega/urbanega razvoja se krepi vloga Ljubljane, Novega mesta in obalnih mest. Nadaljuje se razvoj razpršene poselitve, ki je bolj izražena ob avtocestnih povezavah in mestnih obvoznicah. Nadaljujejo se suburbanizacijski procesi ob večjih mestih in s tem se povečujejo migracijski tokovi, ki so predvsem značilni za avtocestni križ in ljubljansko funkcionalno regijo, ki se širi. Nadaljuje se sprememba namembnosti industrijskih con v mestih in odpiranje proizvodno-servisnih con in nakupovalnih ter rekreacijskih središč ob pomembnejših prometnicah na obrobju večjih mest.

Inačica ima na področju poselitveno-urbanega razvoja dve skrajni obliki monocentrizem ali popolno razpršenost. Monocentrizem pomeni razvoj Ljubljane in njenega neposrednega zaledja $\mathrm{v}$ uspešno, kompetitivno mesto $\mathrm{v} E U$ in hkrati globalizacijo osrednje slovenske regije in Ljubljane s koncentracijo dejavnosti in prebivalstva $\mathrm{v}$ enem centru, $\mathrm{v}$ katerega se stekajo vse investicije. Naglo se povečuje privlačnost Ljubljane in njene metropolitanske regije za lociranje sedežev proizvodnih in še bolj storitvenih podjetij. Najzahtevnejše storitvene dejavnosti in največ visoko kvalificiranih delovnih mest se razvijajo $\mathrm{v}$ osrednji regiji. Zaradi zamud pri pripravi strateških dokumentov in zakonodaje na področju prostorskega razvoja se nadaljujejo slabo nadzorovani procesi urbanizacije in suburbanizacije $\mathrm{v}$ osrednjih razvojnih središčih s poudarjeno stihijsko rastjo Ljubljane in drugih pomembnih urbanih središč. Poselitveni pritiski na obmestja Ljubljane se povečujejo, suburbanizacija je neomejena, kar vpliva na velik primanjkljaj stavbnih zemljišč, in s tem zelo visoke cene zemljišč, velika nesorazmerja na trgu zemljišč in stanovanj. Ekološki pogoji so vse slabši, kar zahteva temeljito prenovo celega mesta in regije. Obrobje zaostaja in postaja naravni rezervat neokrnjene narave. Obrobne regije se povezujejo s sosednjimi središči. Ostali regionalni centri so prepuščeni sami sebi, povečana je dnevna migracija. Širijo se demografsko ogroženi obrobni predeli, kjer se nadaljujejo procesi razvrednotenja kulturne krajine, slabitev drugih mest, izseljevanje iz obrobja.

Popolna razpršenost pomeni manjšanje koncentracije dejavnosti, saj je vse podrejeno načelom tržnosti, delovna mesta so razpršena, ljudje so zadovoljni v svojih ednodružinskih hišah, povečuje se število dnevnih migrantov v vseh smereh. Ni sinergetskih učinkov velikih urbanih aglomeracij. Poseljujejo se velike kmetijske in gozdne površine, občutek pripadnosti manjšim lokalnim skupnostim je vse večji, povečuje se individualizacija. Neracionalno Opremljanje prostora z infrastrukturo je neracionalno. Ekonomski učinek dejavnosti je zmanjšan, in težja je vzpostavitev kakovostnih infrastrukturnih standardov in zagotavljanje standardov varstva okolja. Izgublja se identiteta prostora. Obstaja nevarnost, da postane Slovenija zaledje avstrijskih, italijanskih in madžarskih mest.

Inačica predvideva povečanje suburbanizacije in divjih razraščenih naselj $\mathrm{v}$ okolici večjih mestnih centrov, spremembe bodo počasne, postopne in Slovenija bo ostala relativno nezanimiva, marginalna regija znotraj EU. Nadaljevala se bo politika relativne zaprtosti (kapital, investicije), oziroma kontroliranega odpiranja slovenske države, za ceno nižje rasti. Podeželje bo stagniralo, vendar preživelo ob nižji stopnji standarda. Integracija v Evropo bo minila brez večjih pretresov, Slovenija bo postala tranzitna dežela. Del stanovanjskega 
fonda bo izpraznjen v nerazvitih predelih podeželja, večina teh stanovanj bo pa slabo vzdrževana.

Inačica predstavlja nadaljevanje teženj nenadzorovanega poseganja $\mathrm{v}$ prostor, zunaj komunalno opremljenih in stavbno urejenih zemljišč, s poudarkom na zasebni pobudi.

Razpršeni razvoj pomeni tudi ohranitev enostopenjske lokalne samouprave z morebitnimi oblikami medobčinskega sodelovanja, ki pa so omejene na razvoj posamičnih infrastrukturnih projektov. Male občine pa brez koordinacije ne morejo zagotavljati enakomernega regionalnega razvoja. Celotno odgovornost za stanovanjsko oskrbo je prenešena na občino.

V pogojih visoke razpršenosti lastništva nad zemljišči brez državnih oz. regionalnih intervencij je možno predvsem nadaljevanje obstoječih teženj razpršene poselitve. Postopno se zapolnijo vse vrzeli v obcestnem prostoru in model urbano ruralnega kontinuuma se iz dosedanjih območij suburbanizacije prenese na preostala območja. Že prisotni primanjkljaji na komunalni infrastrukturi se povečajo in s tem povezane nevarnosti nadaljnjega izgubljanja potencialnih vodnih virov.

Na področju razvoja infrastrukture se povečujejo razlike v stopnji informatizacije in ponudbe virtualnih storitev med večjimi mesti in podeželjem. Zaradi parcialnega reševanja posameznih infrastrukturnih sistemov (npr. energetski, cestni, železniški) ni možno doseči sinergetskih učinkov postavitve in vzdrževanja. Nadaljuje se rast motorizacije, kar vodi do povečanja potreb po parkirnih površinah (kritično za urbana jedra in velike stanovanjske soseske). Pri izvajanju nacionalnih razvojnih programov (še posebej cestnega) so prizadevanja usmerjena predvsem $\mathrm{v}$ izboljšanje prometne prehodnosti, manj pa $\mathrm{v}$ povečanje prometne središčnosti oziroma vozliščnosti Ljubljane, Maribora in Kopra. Velika tuja industrijska podjetja, ki so običajno locirana izven Ljubljane, zanima predvsem kakovostna prometna dostopnost do njihovih podružnic in kakovostne obstoječe energetske infrastrukture. $\mathrm{Na}$ področju javnega prometa pride zaradi nekonkurenčnosti in slabe ponudbe javnega (cestnega in železniškega) prometa do ukinjanja posameznih povezav in zmanjševanja voženj.

Na področju varovanja in razvoja okolja/krajine se povečuje že prisotni primanjkljaj na komunalni infrastrukturi (npr. vodooskrba, zajem in čiščenje odpadnih voda), kar prispeva k večji obremenitvi okolja. Nenadzorovani posegi v prostor spreminjajo vredne krajinske vzorce; znižujejo prostorsko identiteto ter bistveno otežujejo varstvo naravne in kulturne dediščine. Nadaljujejo se spremembe v kulturni krajini zaradi opuščanja kmetijske dejavnosti: na privlačnejših območjih pozidava, drugje zaraščanje. Na področju krajine prihaja do popolne fragmetntacije $\mathrm{v}$ obliki razpršene poselitve po prostoru. Krajinska območja so prepredena $\mathrm{z}$ infrastrukturo, poselitev zaseda kakovostna naravna in kulturna območja. Prevladuje popolna fragmentiranost naravnih območij, razdrobljeno intenzivno in ekstenzivno kmetijstvo, neracionalno izkoriščanje mineralov. Območja intenzivnih naravnih procesov so podrejena poselitvi. Omrežje naravne dediščine ni izpostavljeno. Prisotna je močna ekološka obremenitev. Izginja krajinska pestrosti v prostoru. Razvojna prednost v razmeroma dobro ohranjenem in pestrem naravnem okolju se zgublja, kar ogroža tudi nadaljnji razvoj turizma. Stopnjujejo se težave z urejanjem odlaganja komunalnih odpadkov na medkrajevni ali celo regionalni ravni. Razdrobljenost onemogoča racionalno delovanje posameznih sistemov. 
Razvoj poteka po sedanjih trendih, prednost se daje razvoju, varstvo narave pa je minimalno. Inačica omogoča razvoj brez vidikov varstva. Rezultat takega razvoja se bo kazal $\mathrm{v}$ velikih spremembah $\mathrm{v}$ ekosistemu, biotopih, izginjanju in predrugačenju flore in favne, propadanju habitatov, spremembah vodnega režima, količinskih in kakovostnih spremembah vodnih virov in razvrednotenje krajinske zgradbe

Nadaljuje se normativno varstvo vseh območij naravnih in kulturnih vrednot. Na ta način naj bi se uveljavljal sistem prepovedi in omejevanja razvojnih dejavnosti v skladu $\mathrm{s}$ cilji varstva na posameznih varovanih območjih. Omejevanje razvoja bi bilo treba predvideti v okviru podobmočij z različno strogimi režimi varstva, ki pa pred razglasitvijo zavarovanih območij niso opredeljena. Prostorski razvoj teh območij bo vsekakor zelo omejen, predvsem pa je slabost variante $\mathrm{v}$ tem, da predpostavlja neke vrste rezervacijo prostora, ki glede na obstoječe podatke in zahteve pristojnih institucij danes obsega skoraj polovico ozemlja in ne dopušča enakovrednega vrednotenja prostora ob načrtovanju različnih posegov. Prostorski razvoj na območjih varstva bi bil zelo omejevan, zato bi večina razvojnih posegov potekala na preostalem delu ozemlja, zunaj varovanih območij. S tem bi bili tu razvojni pritiski bistveno večji, kar bi posledično lahko vodilo k razvrednotenju prostora. Še nadalje se uveljavljajo varstveni režimi s sistemom prepovedi in omejevanja na vseh varovanih območjih.

Na področju regionalnega razvoja se povečujejo regionalne razlike. Nadaljuje se razvoj osrednjih delov Osrednjeslovenske, Gorenjske, Dolenjske in Primorske regije. Brezposelnost se povečuje predvsem v Pomurski, Podravski, Savinjski in Zasavski regiji. Nadaljuje se depopulacija Pomurske, Posavske in Kraško-obalne regije. Nadaljuje se večanje števila novih občin, mikro zapiranje in neproduktivno tekmovanje. Raba regionalnih virov (npr. problem črpanja mineralnih surovin) je skromna, ker ne pride do medobčinskega sodelovanja (in konsenza) na večjih projektih.

\section{INAČICA INTENZIVNEGA RAZVOJA}

Inačica temelji na tržnem liberalizmu in izkoriščanju vseh naravnih virov, intenzivnem razvoju na vseh področjih, na migracijah iz Evrope v Slovenijo in koncentraciji kapitala, intenziviranju pridelave $\mathrm{v}$ kmetijstvu in gozdarstvu, in močno razvitem infrastrukturnem omrežju. Razlik med mesti in podeželjem ni, prevladuje urbana krajina in intenzivna kulturna krajina, nastajajo nove krajine, prisotno je zaraščanje, velika izraba rečnega potenciala tudi v prometne namene, povečan promet preko države, večanje obremenjevanja okolja.

Na področju poselitvenega/urbanega razvoja se razvoj poselitve omeji ob razvojni osi Z-V predvsem v obalnem somestju, Ljubljani in Mariboru. Pride do razvoja močnih tehnološko - informacijskih centrov v Ljubljani, Mariboru in Kopru (npr. »teleporti«). Povečana je dnevna migracija in koncentracija razpršene gradnje v prometnih koridorjih, kjer prihaja do razvoja proizvodno trgovskih con na novih nepozidanih površinah. Trije razvojni poli pomenijo zaprtost $\mathrm{v}$ gravitacijska območja posameznih mest, večanje regionalnosti, slabo dostopnost do storitev $\mathrm{v}$ obrobnih območjih, koncentracijo poselitvenih pritiskov, slabo 
povezanost med posameznimi območji, zgoščevanje ob osi JZ - SV, obsežno dnevno migracijo, suburbanizacijo ob prometni osi, slabšo navezanost na os SZ - JV, povečevanje regionalnih razlik in nepovezanost med regijami, praznjenje obrobja, premosorazmerno pojemanje razvoja z oddeljevanjem od osi, krepitev razvojne diagonale, ki razpolavlja Slovenijo.

Na področju razvoja infrastrukture so posegi omejeni na naložbe za avtoceste, hitre železnice in telekomunikacije. Razvoj javnega prometa je osredotočen na razvojno os Z-V. Le-ta je tudi izhodišče za razvoj prometnih terminalov v Ljubljani, Mariboru in Kopru. Vzpostavljen je prometni križ 'hitre'/izboljšane železnice: S-J: Jesenice - Ljubljana - Novo mesto - Zagreb; Z-V: Trst - Ljubljana - Maribor (zveza Budimpešta).

Na področju varovanja in razvoja okolja/krajine prihaja do opuščanja kmetijske pridelave in spremembe v krajini (zaraščanje, pozidava) na pretežnem delu površin. Posodabljanje kmetijske pridelave poteka brez upoštevanja krajinskih in ekoloških izhodišč. Uvaja se »industrijski« tip kmetijstva (monokulture, plantažni nasadi). Povečujejo se razvojni pritiski (tuji kapital) na krajinsko najvrednejše predele in pozidava obale (Luka, turizem). Nastajajo obsežni degradirani prostori na območjih tradicionalne industrije. Izkoriščanje naravnih (predvsem vodnih in mineralnih) virov je prekomerno in nenadzorovano.

Inačica zagotavlja velike razvojne možnosti in le minimalno stopnjo varstva naravnih in kulturnih vrednot in sicer predvsem v okviru rezervatnega varstva majhnega števila prostorsko zelo omejenih območij, tako da je obseg območij prednostnega varstva vrednot minimalen. Območja prednostnega razvoja so v tem primeru po obsegu največja, manjši del ozemlja države pokrivajo območja, kjer je treba razvoj načrtovati ob upoštevanju zahtev varstva naravnih in kulturnih vrednot. Raba naravnih virov je opredeljena z medsebojnim usklajevanjem različnih sektorjev, ki temelji na ugotavljanju ustreznosti prostora za posamezne rabe in zagotavlja racionalno rabo prostora ob le minimalni stopnji ohranjanja obsega in kakovosti naravnih virov. Inačica ne zagotavlja zadostne stopnje obnovljivosti naravnih virov, hkrati pa predpostavlja varstvo naravnih in kulturnih vrednosti samo na delu državnega ozemlja, kar lahko vodi k pojavom razvrednotenj v preostalih, razvojnim dejavnostim namenjenih območjih.

Varovalni vidik planiranja je uveljavljen samo v strogo varovanih naravnih območjih in v bližini večjih naselij. Razvoj dejavnosti na istem prostoru pomeni, da predstavljajo vsa obstoječa in predvidena območja rab za posamezne dejavnosti prednost na vseh lokacijah, ki ne sovpadajo z naravno najbolj ohranjenimi območji oziroma z območji največje ranljivosti prostora in $z$ območji v bližini večjih poselitvenih območij. Tako se npr. v raziskovalnih območjih mineralnih surovin zadržuje razvoj tistih dejavnosti, ki bi ovirale predvideno rabo mineralne surovine $\mathrm{v}$ prihodnosti ( npr. urbanizacijo), v obstoječih območjih pa tiste dejavnosti, ki bi ovirale razvoj in predvidene širitve nadaljnje rabe oziroma tudi tiste, katerih razvoj bi bil oviran zaradi velikih okoljskih vplivov rabe na prostor ( npr. zaradi sprememb površine ozemlja ali zaradi sprememb stanja drugih naravnih virov in okoljskih kakovosti).

Na področju regionalnega razvoja ustanovi država regionalne razvojne agencije (tehnične regije) zaradi spodbujanja tehnološke modernizacije in prestrukturiranje proizvodnje. V kriznih regijah (npr. Maribor, Zasavje) potekajo občasne intervencije države. 
Tudi na področju razvoja posameznih sektorjev je razvoj le delno omejevan, nekateri sektorji so podrejeni oziroma usmerjeni v delno varstvo (kmetijstvo, gozdarstvo, rabo naravnih virov). Varstvo narave je omejeno. Poudarjen je razvojni interes sektorja, tako da so iz sektorskih načrtov neposredno povzeta obstoječa in potencialna območja lesnoproizvodnega izkoriščanja (in rabe drugih nelesnih proizvodov), varovalni interes pa je poudarjen le v strogo varovanih območjih. Razvojne težnje neposredno povzemajo sektorska potencialna območja rabe, varovalne zahteve pa se uveljavljajo le v strogo varovanih območjih in v bližini večjih naselij. Potencialna razvojna območja predstavljajo vse lokacije, kjer sektor planira v naslednjem planskem obdobju nadaljnjo rabo. Samo v strogo varovanih območjih in v bližini mest in večjih naselij se na osnovi varstvenih izhodišč uveljavi opuščanje in sanacija obstoječih območij rabe v oblikah, primernih konkretnemu območju.

Razvojni interes sektorja, $v$ smislu ekonomske rabe naravnega vira, je predviden $\mathrm{v}$ vseh območjih, kjer za to obstajajo ugotovljeni potenciali. Na področju gozdarstva bi v praksi to pomenilo velik obseg območij gozdov rezerviranih za razvoj, t.j za pridobivanje lesnih gozdnih dobrin, kjer bi bili drugi interesi sektorja (varovalni interesi na območjih poudarjenih ekoloških in socialnih funkcij) bistveno omejevani. Hkrati to pomeni tudi veliko omejitev za interese tistih dejavnosti, ki bi ta razvoj lahko ovirale (npr. infrastaruktura) ali pa bi bile zaradi tega razvoja ovirane (npr. varstvo naravnih vrednot, vodno gospodarstvo). Rezultat uveljavitve variante bi pomenil malo strogo varovanih območij, kar bi pomenilo dvoje: na eni strani manj možnosti za intenzivno varovanje ekoloških in socialnih kakovosti gozda, na drugi strani pa veliko manevrskega prostora za dopustitev razvoja dejavnosti, ki sicer ne ovirajo lesne proizvodnje, so pa lahko v izrazitem konfliktu z varovanjem obstoječih kakovosti prostora.

Inačica pomeni minimalno upoštevanje (oziroma $\mathrm{v}$ posameznih področjih neupoštevanje) okoljskih omejitev tržno ozko zasnovanega gospodarskega in socialnega razvoja.

\section{INTENZIVNO VARSTVENA INAČICA}

Intenzivno varstvena inačica se nanaša na Slovenijo kot ekološki rezervat. Inačica pomeni najvišjo stopnjo varstva vrednot in ob tem še zadovoljive razvojne možnosti. Z njim naj bi se uveljavilo normativno varstvo naravnih in kulturnih vrednot na skoraj polovici prostora, kar hkrati pomeni, da naj bi bile na teh območjih razvojne dejavnosti omejen ali celo izključene. Območja prednostnega varstva vrednot so po obsegu zelo velika, precejšen del ozemlja države pokrivajo tudi območja, kjer je treba razvoj načrtovati ob upoštevanju zahtev varstva naravnih in kulturnih vrednot. Najmanjša so območja prednostnega razvoja, v katerih ima varstvo vrednot le manjši pomen. Tako radikalen varstveni pristop presega mednarodne zahteve na tem področju in vsekakor pogojuje zelo enostranski prostorski in gospodarski razvoj, omejen $\mathrm{z}$ varstvom zatečenih prostorskih vrednot in z zahtevami za sanacijo obstoječih razvrednotenj. Razvijalo naj bi se npr. kmetijstvo z uporabo tradicionalnih tehnologij obdelovanja zemljišč; gozdarstvo kot gospodarska dejavnost le na majhnem delu gozdnih površin, ki nimajo večjih ekoloških vrednosti; vodnogospodarski ukrepi le na že razvrednotenih vodotokih in sicer v smeri sonaravnega urejanja vodnega in obvodnega 
prostora; pridobivanje mineralnih surovin samo $\mathrm{v}$ okviru sanacij obstoječih kopov; poselitev le v okviru strnjene gradnje na neposrednem obrobju večjih naselij ob upoštevanju lokalne tipologije gradnje in podobno.

$\mathrm{V}$ prostor se ne posega $\mathrm{z}$ večjimi posegi, intenzivno kmetijstvo se ohranja oziroma izvaja na območjih, ki niso ranljiva, prevladuje ekstenzivno kmetijstvo predvsem na območjih, kjer je možno onesnaževanje podtalnice, intenzivnejše ohranjanje in vzdrževanje kulture krajine, razvoj ekološkega turizma, zaraščanje območij manj kakovostnih krajin. Večji delež površin pokrivajo naravni parki, varstvo okolja postane najpomembnejše področje ravnanja s prostorom, infrastruktura je namenjena zadovoljevanju lastnih potreb, poselitev se razvija znotraj sedanjih meja, koncentracija poselitve v večjih regionalnih središčih, sanacija degradiranih območij.

Varovalni interesi imajo tudi na sektorskem področju prednost pred razvojem. Tako ima npr. varovanje vodnega in obvodnega prostora prednost pred razvojem. Taka usmeritev pomeni varovanje čim večjega obsega vodnega in obvodnega prostora in posledično ostro omejevanje drugih rab v tem prostoru. Razvoj se lahko uveljavlja le na območjih, ki so za to najmanj ranljiva (soočanje s splošno ranljivostjo prostora), hkrati pa izkazujejo stanje ali potencial za največjo ekonomsko učinkovitost. Na področju gozdarstva pomeni inačica bolj ali manj intenzivno varovanje vseh območij gozdov, razen tistih, ki izkazujejo izjemen lesnoproizvodni potencial in ki so obenem tudi najmanj ranljiva za gospodarsko izkoriščanje. (npr. območja gozdov s 1. stopnjo poudarjenosti proizvodnih funkcij na območjih majhne ranljivosti). To pomeni, da je pretežna večina območij gozda podrejena bolj ali manj strogemu varstvu, kar bi se odražalo v večjem obsegu strogo varovanih območij gozdov (z velikim obsegom normativnega zavarovanja) in v manjšem območij gozdov z zadržanim razvojem, kjer naj bi bilo predpisano obvezno usklajevanje z drugimi dejavnostmi. Območja razvrednotenih in poškodovanih gozdov bi ostala izven razvoja oz. varstva in bi bila obravnavana problemsko, kot posebna območja. Inačica temelji na strogem varovanju naravnih in ustvarjenih vrednot. Njen namen je zavarovati čim več gozdnih območij pred morebitnimi vplivi gozdnogospodarske oziroma lesnoproizvodne rabe in pomeni izrazito omejevanje razvoja, tako sektorskega kot drugih dejavnosti.

Vsa sektorska potencialna območja so soočena $\mathrm{z}$ varstvenimi merili. Načrtovanje rabe gozdnega bogastva poteka samo $v$ tistih območjih, ki predstavljajo najmanjši možni vpliv na okolje in so obenem najbolj perspektivna. Načrtovanje rabe poteka torej samo na tistih območjih, ki predstavljajo najmanjši možni vpliv na prostor in okolje in so obenem območja največjih razvojnih potencialov za posamezne dejavnosti Taka območja pa so določena na podlagi dveh meril: ranljivosti prostora in perspektivnosti območja rabe.

Inačica uveljavlja varstveni vidik, kar pomeni, da je raba podrejena varstvenim izhodiščem oziroma usklajujejo $\mathrm{z}$ ostalimi dejavnostmi in ne predstavljajo prednostne dejavnosti. Inačica temelji na maksimalnem ohranjanju in varovanju (po)krajinske in biotske raznovrstnosti. Sanacija in neodpiranje se tako poleg strogo varovanih območij uveljavi tudi na vseh območjih velike ranljivosti, ki sicer niso normativno varovana, zadržan razvoj pa je uveljavljen na vseh ostalih območjih majhne ranljivosti, ki niso opredeljena kot najbolj perspektivna . 


\section{INAČICA TRAJNOSTNEGA RAZVOJA}

Inačica trajnostnega razvoja temelji na trajnostnem razvoju kot izhodišču in cilju prostorskega razvoja.

Na področju poselitvenega/urbanega razvoja prihaja do zgoščevanja urbanizacije ob dveh primarnih nacionalnih razvojnih oseh: (Z-V) Primorska konurbacija - Ljubljana Maribor in (S-J) Kranj - Ljubljana - Novo mesto ter centrov ob regionalni razvojni osi. S postopno krepitvijo procesov reurbanizacije, predvsem $v$ regionalnih središčih se upočasni proces suburbanizacije. Vzpostavi se dejavna zemljišča politika v regionalnih središčih, razvojnih centrih in pomembnejših središčih turističnega pomena. Urbani razvoj je zasnovan na 'znanju', enoten info-urbani prostor visoko razvite informacijske družbe in razvoju informatiranja $\mathrm{v}$ urbanem okolju, ki povezuje gospodarske, družbene in kulturne akterje. Razvoj poselitve je podprt z učinkovitim urbanističnim planiranjem ter oblikovanjem in upravljanjem urbanega prostora (vključno z bogato kulturno ponudbo). Urbano okolje je kakovostno dobro dostopno, varno, estetsko in z razpoznavno podobo, regionalno povezano.

Razvoj velikih, srednjih in malih mest je $\mathrm{v}$ skladu $\mathrm{z}$ razvojem podeželja, $\mathrm{z}$ racionalno razporeditvijo dejavnosti, delovnih mest in prebivalcev ter upoštevanjem značilnosti poselitvenega vzorca in upoštevanjem identitete na državni, regionalni in lokalni ravni. Prihaja do izboljšanja stanja okolja in enakomerne porazdelitve obremenitev okolja. Povečuje se medmestna povezanost, enakomerna razporejenost infrastrukture, premišljeno poseganje v prostor, trajno uravnotežen razvoj urbanega in podeželskega prostora, boljše prometne povezave po državi, boljša ponudba dejavnosti in delovnih mest po državi, vzpodbujanje lokalne iniciative, krepitev obmejnih območij, varovanje kulturne identitete, manjšanje okoljskih obremenitev v središčih, večja prepoznavnost prostora in identitete z njim, omejevanje rasti večjih središč, večja dinamika v prostoru, stabilna zgradba zaradi lokalnih središč med večjimi središči, možnost doseganja optimalnih razmerij med urbanim prostorom in krajino, med mestom in podeželjem.

Modificirana mrežna inačica (mozaična inačica) poselitve/urbanega razvoja v različnih možnih prostorskih oblikah je najbolj realna, smotrna, trajnostna, vzdržna in učinkovita, saj pomeni sonaraven, vzdržen razvoj, enakomerno napajanje prostora in nadgradnjo policentričnega razvoja, ker ohranja drobno mrežno strukturo naselij, komunikacij in rabe tal, okoljsko rezistentnost, ohranja identitete mest, vasi, krajinskih celot in drobnih prostorskih struktur, pomeni najmanjše odmike od razvojnih teženj, povezuje Slovenijo s prostorsko organizacijo držav EU, sosednjih regij in dežel, vzpodbuja regionalni razvoj, spodbuja sodelovanje in samoupravo ljudi na lokalni ravni, pomeni optimizacijo lokalnih naravnih virov, zaščito najpomembnejših naravnih bogastev, pomeni sonaravno poseganje v prostor, smotrno in vzdržno rabo naravnih virov ter smotrno adaptacijo naravnega okolja, zmanjšuje energetske in prehrambeno odvisnost ter omogoča največjo proizvodnjo hrane, daje prednost kmetijstvu v območjih z najugodnejšimi naravnimi pogoji, spodbuja ekosocialni model kmetijstva v slabših naravnih razmerah v goratih in obmejnih predelih, omogoča sočasno načrtovanje kmetijstva s turizmom in rekreacijo, smiselno dopolnjuje kmetijstvo z gozdarstvom, kompenzira velike sisteme urbane krajine $\mathrm{z}$ velikimi strnjenimi kompleksi naravne krajine, povezuje in dopolnjuje območja varstva okolja $\mathrm{z}$ ustreznimi prostori varovanega 
prostora sosednjih držav, varuje vire pitne vode, zmanjšuje energetske soodvisnosti s spodbujanjem rabe naravnih virov, varuje skromna rudna bogastva, omogoča optimalno dostopnost do vseh delov Slovenije, pravo velikost mest, krepi lokalno in državno raven oskrbe, spodbuja razvoj metropolitanskih območij, omogoča optimalno rabo družbene infrastrukture, decentralizacijo industrijske proizvodnje, zmanjšuje stanovanjske potrebe in omogoča optimalen razvoj turizma na lokalni ravni.

Na področju razvoja infrastrukture pride do nadgradnje in maksimiranja izkoristka obstoječih informacijskih omrežij ter uvajanje novih oblik (npr. brezžični internet za informatizacijsko težko dostopna in slabo poseljena območja). Prometna politika države in mest je usklajena. Povečan je pomena železnic v medmestnem in obmestnem JP. JP v mestih in druge alternativne oblike mobilnosti (npr. nemotorizirana prometna sredstva, javni avtomobili) se povečujejo. Vzpostavljene so medregionalne (tudi mednarodne) povezave med regijami/mesti izven prometnega »križa« in razvoj logističnih centrov, predvsem Luke Koper v povezavi s severnojadranskimi pristanišči (kot konkurenca severnomorskih) ter postavitev prometnih terminalov: Ljubljana, Koper, Maribor in Nova Gorica. Vzpostavljen je sistem prometnega križa »hitre«/izboljšane železnice: S-J: Jesenice-Lesce-Kranj-BrnikLjubljana-Novo mesto; Z-V: Nova Gorica-Postojna (zveza Koper)-Ljubljana-Celje-Maribor (zveza Gradec)-Murska Sobota (zveza Budimpešta).

Na področju varovanja in razvoja okolja/krajine se aktivirajo lokalni razvojni dejavniki in ohranja regionalna kulturna identiteta. Z uvajanjem novih funkcij se ohranja poseljenost in zmanjšuje pritisk na naravno zaledje mest in se obuja interes za podeželje (dislocirane oblike dela, potrebe po rekreaciji, zahteve po višji bivanjski kakovosti). Zavarovano je $30 \%$ ozemlja Slovenije z različnimi oblikami varstvenih režimov. Ohranjeni so najvrednejši krajinski vzorci z uvajanjem alternativnih oblik pridelave in posodabljanjem pridelovalnega prostora ob upoštevanju tudi ekoloških in kulturnih motivacij. Naložbe v komunalno infrastrukturo in čiste tehnologije, ki omogočajo izboljšanje stanja onesnaženosti okolja.

Inačica zagotavlja vzdržno rabo (gospodarsko učinkovita, ekološko sprejemljiva in oblikovno skladna) vseh sestavin in potencialov prostora v skladu z njegovimi značilnostmi. Inačica pomeni ohranjanje vitalnega podeželja in kmetijske krajine oziroma intenzivno kmetijsko rabo le na najkakovostnejših zemljiščih. Prevladuje ekstenzivno kmetijstvo z regionalno značilnimi pridelki, diverzifikacija podeželja in sožitje med mestom in podeželjem. Krepijo se regionalna središča in manjša podeželska naselja, obseg gozdov ostane enak, ohranjanje in vzpostavljanje biološke in krajinske raznovrstnosti, največja območja degradacij se sanirajo, vzdržen razvoj in varstvo na celotnem območju države, zavarovanje najvrednejše naravne in kulturne krajine, vzpostavljanje omrežja povezav med območji naravne in kulturne dediščine, izjemna raznovrstnost in pestrost prostora, lokalna identiteta, bogastvo kultur kot geografski potencial za turizem, bivalno prijazno in zdravo okolje, dodatne povezave med regionalnimi centri in podeželskimi naselji, zavarovanje pitne vode.

Inačica temelji na usklajenosti razmerja med razvojnimi in varovalnimi interesi in hkrati zagotavlja največ možnosti za usklajevanje interesov v postopkih načrtovanja. Inačica je najprimernejša za doseganje optimalne stopnje razvoja in varstva.

Inačica omogoča vzpostavitev skladnejših razmerij med razvojnimi in varstvenimi interesi. Ponuja največje možnosti za vzpostavitev racionalne rabe prostora, ki bo lahko omo- 
gočila gospodarsko učinkovito krajino in hkrati ohranila najvrednejša naravna območja in kulturno krajino kot nosilko kulturnih vrednot v slovenskem prostoru. Uresničitev variante zahteva najvišjo stopnjo usklajevanja med razvojnimi sektorji, ki bi jim bilo treba opredeliti možnosti za prostorski razvoj z določanjem ustreznosti prostora za posamezne dejavnosti. Območja prednostnega razvoja so razmeroma majhna, precejšen del ozemlja države pa pokrivajo območja, kjer je treba razvoj načrtovati ob upoštevanju zahtev varstva naravnih in kulturnih vrednot. $\mathrm{Na}$ ta način naj bi zagotoviti racionalno rabo prostora in s tem kar najboljše varstvo naravnih virov. Medtem ko naj bi varstvo največjih naravnih in kulturnih vrednot zagotavljalo z rezervatnim varstvom v okviru majhnega dela ozemlja in v precejšnjem delu s poudarjenimi varstvenimi cilji , naj bi varstvo naravnih in kulturnih vrednot $\mathrm{v}$ preostalem prostoru zagotavljali z vključevanjem varstvenih interesov v postopke načrtovanja posegov $\mathrm{v}$ prostor na planski in izvedbeni ravni.

Normativno varstvo in vključevanje varstvenih ciljev v postopke načrtovanja pomeni varstvo najvrednejših naravnih in kulturnih vrednot $\mathrm{z}$ normativnim varstvom, torej z razglašanjem zavarovanih območij, in predpostavlja varstvo preostalih naravnih in kulturnih vrednot $\mathrm{z}$ ustreznim vključevanjem varstvenih ciljev v postopke prostorskega načrtovanja. Varstveni režimi naj bi bili opredeljeni vnaprej za majhna in maloštevilna območja varstva naravnih vrednot (npr. naravni rezervati), v katerih naj se ne bi uveljavljale nikakršne razvojne dejavnosti in območja kulturnih vrednot (npr. izjemne krajine), kjer naj bi bil razvoj zelo omejen. $\mathrm{Ob}$ dejstvu, da je sistem rezervatnega varstva že uveljavljen v našem prostoru in predvsem tudi v tujini, se zdi ta inačica ustrezna, saj prinaša vnaprej opredeljena območja, ki bi se jim moral razvoj zaradi posebnih vrednosti izogniti ali pa vsaj zelo prilagoditi. Inačica pomeni vmesno stopnjo, ki predpostavlja rezervatno varstvo manjših prostorskih enot (največja stopnja omejevanja posegov v prostor), $v$ preostalem prostoru pa uveljavljanje načel varstva naravnih in kulturnih vrednot ob vsakokratnem načrtovanju posegov $\mathrm{v}$ prostor. Na strokovni ravni se kot najustreznejša in najbolj verjetna izkaže opcija, ki predpostavlja veliko usklajevanja in že v fazi priprave plana dobro poznavanje konkretnih prostorskih razmer na posameznih območjih naravnih in kulturnih vrednot ter vnaprejšnje opredeljevanje najvrednejših območij, v katerih naj bi se uveljavilo rezervatno varstvo naravnih in kulturnih vrednot.

Na področju regionalnega razvoja pride do oblikovanja regij/pokrajin z davčno avtonomijo, soliden partner za medregionalno sodelovanje na evropski ravni. Regionalne razlike se zmanjšujejo tudi zaradi spodbujanja medregionalnega in prekomejnega sodelovanja $\mathrm{z}$ regijami sosednjih držav. Opušča se historične regije, ki nimajo več življenjskih možnosti (posledica razvojne inercije še od zgodnjega srednjega veka). Razvijajo se lokalna in regionalna informacijska omrežja, ki spodbujajo razvoj virtualne lokalne demokracije. Spodbujajo se različne oblike teledela, predvsem v ruralnih območjih depopulacije (npr. Pomurske, Posavske, Kraško-obalne regije) ter razvoj inovacijsko - informacijskih inkubatorjev v regionalnih središčih kot gonilne sile gospodarskega razvoja.

Na področju sektorjev gre za selektiven razvoj, brez pomembnejših rušilnih dejavnosti v okolju. Varstvo ima večjo težo, razvojne težnje so usmerjene, nekatere dejavnosti so prepovedane. Na področju razvoja sektorjev so razvojne in varstvene težnje usklajene tako, da so sektorska potencialna območja rabe razvrščena glede na potrebe z državnega in regio- 
nalnega vidika. Načrtovanje rabe poteka samo v najbolj perspektivnih območjih, v ostalih pa so uveljavljena varstvena izhodišča s sanacijo in zadrževanjem odpiranja novih razvojnih območij v strogo varovanih območjih in $\mathrm{z}$ usklajevanjem različnih rab v ostalih, manj ranljivih območjih.

Tako pomeni optimalen razvoj vodnega in obvodnega prostora ohranjanje kolikor je le mogoče naravnega stanja vodnega in obvodnega prostora, doseganje uravnoteženosti med naravno ohranjenimi območji in območji, ki so v antropogeni rabi, ohranjanje in stalno povečevanje ekoloških, kulturnih in rekreacijskih potencialov vodnega in obvodnega prostora, omogočanje posodabljanja določenih delov gospodarskega vodnega in obvodnega prostora ter saniranje obstoječih in preprečevanje novih razvrednotenj v vodnem in obvodnem prostoru.

Varovanje vodnega in obvodnega prostora ima prednost pred razvojem. Taka usmeritev predvideva varovanje čim večjega obsega vodnega in obvodnega prostora in posledično ostro omejevanje drugih rab $\mathrm{v}$ tem prostoru in s tem ohranjanje kolikor je le mogoče naravnega stanja vodnega in obvodnega prostora. $\mathrm{V}$ vodnem in obvodnem prostoru se povsod $\mathrm{v}$ čim večji možni meri ohranja in stalno povečuje ekološke, kulturne in rekreacijske potenciale in se s tem zagotavlja zdrave življenjske razmere, ekološko pestrost in estetsko vrednost kot tudi dovolj kakovostnih območij za prosti čas in rekreacijo. Razvoj v vodnem in obvodnem prostoru je selektiven in podrejen varstvu količin, kvalitet, raznolikosti vode, brez pomembnejših rušilnih dejavnosti v okolju, nekatere dejavnosti so v določenih območjih prepovedane. Vodni in obvodni prostor je na ta način varovan pred posegi, obstoječa območja razvrednotenja pa so v čim večji meri renaturirana. Najvrednejše vodotoke in druge vodne pojave (presihajoča jezera, podzemne vode ipd.) ter mokrišča so zaradi velike ekološke in krajinske vrednosti zavarovani. Razvoj naselij, kmetijstva in drugih dejavnosti na območjih z izrazito naravno dinamiko je omejena. V kolikor ne ogrožajo varnosti ljudi in materialnega bogastva, so prepuščena naravnim procesom.

Območja z visoko stopnjo naravne ohranjenosti so prepuščena naravnim procesom, ohranjanju biotske raznovrstnosti, oblikovanju omrežja zavarovanih območij. V območjih visoke stopnje kulturne ohranjenosti je razvoj, vzdrževanje in obnavljanje obstoječe ali nove rabe takšno, da bo ohranjena vodna in obvodna krajina in omogočen razvoj nove krajine.

Inačica na področju rudarstva izhaja iz predpostavke, da vsa območja rab mineralnih surovin glede na potrebe po surovini in v smislu ohranjanja dejavnosti niso enako pomembna. Inačica temelji na rangiranju sektorskih potencialnih območij rab z vidika državnih in regionalnih potreb po mineralni surovini, kar služi kot podlaga za opredelitev državno pomembnih in najbolj perspektivnih lokalno /regionalno pomembnih območij rab. Raba je načrtovana samo v tistih območjih, ki so opredeljena kot strateško pomembna in najbolj perspektivna, sanacijo in preprečevanje odpiranja novih območij v naravno najbolj ohranjenih območjih - strogo varovana območja in v bližini večjih mest, vsa ostala območja pa se soočajo z ranljivostjo prostora, na podlagi česar se opredeli tudi smer njihovega nadaljnjega razvoja; usklajevanje z drugimi razvojnimi interesi, omejevanje drugih rab, postopno ukinjanje rabe in sanacije prostora.

Varstveni vidik se tako poleg strogo varovanih območij in v bližini večjih naselij uveljavi tudi v vseh območjih velike in majhne ranljivosti prostora, po merilu večje ranljivosti prostora zadržanega razvoja dejavnosti glede na ostale rabe. 
Razvojni interesi na področju gozdarstva so uveljavljeni na območjih, ki izkazujejo stanje ali potencial za največjo ekonomsko učinkovitost, v ostalih območjih gozdov pa prihaja do usklajevanja varovalnih in razvojnih interesov z varovanjem, z usklajevanjem različnih rab ter s sanacijo. Razvojni interesi gozdarskega sektorja se npr. uveljavljajo na območjih, ki izkazujejo stanje ali potencial za največjo ekonomsko učinkovitost in so sektorsko opredeljeni (območja gozdov s 1 . stopnjo poudarjenosti proizvodnih funkcij), v ostalih območjih gozdov pa prihaja do izključenega izjemno omejenega ali pa zadržanega razvoja (lesnoproizvodnega izkoriščanja) in do bolj ali manj intenzivnega uveljavljanja varovalnih interesov. To bi v praksi pomenilo strogo varovanje naravnih in ustvarjenih danosti ter prepoved razvoja oz. gospodarske rabe (in drugih dejavnosti) v strogo varovanih območjih, to je v območjih, ki so tudi normativno zavarovana (npr. območja varovalnih gozdov in gozdov s posebnim namenom ter območij nad gozdno mejo). V ostalih območjih gozdov, kjer prihaja do prepletanja različnih funkcij in rab ter s tem tudi do ustvarjanja konfliktnih stanj, bi z usklajevanjem različnih rab v postopkih prostorskega načrtovanja, ob obvezni vključitvi okoljevarstvenih postopkov in orodij, omogočili zadržan razvoj, ob hkratnem varovanju naravnih in ustvarjenih vrednot. Območja razvrednotenih in poškodovanih gozdov so obravnavana problemsko, kot posebna območja.

Na področju okolja pomeni inačica optimalno sonaravno zasnovan prostorski razvoj, ki temelji na skrbnem upoštevanju ekološkeg ravnovesja in vrednot dediščine, hkrati z okolju in njegovim samočistilnim in regeneracijskim zmogljivostim (omejitve okolja) prilagojenim poselitvenim, ekonomskih in tehnološkim razvoju. Vsebine varstva okolja vključijo z vidika optimalnega sonaravno zasnovanega prostorskega načrtovanja poselitve, infrastrukture in pokrajinske rabe. Zmerna stopnja onesnaženosti okolja in regionalno omejena območja kritične onesnaženosti, delno izčrpani naravni viri, pretežno nenadzorovano ali celo stihijsko razmeščanje urbanizacije in drugih prostorsko pomembnih dejavnosti ter dosežena stopnja materialnega blagostanja in okoljske ozaveščenosti so temeljni notranji, prehod na sonaravno razvojno pot v EU že v 90. letih pa zunanji argumenti za reševanje prostorsko relevantnih okoljskih problemov, s kombinacijo kurativnih in preventivnih ukrepov. Temeljna okoljska zahteva trajnostnega sonaravnega prostorskega razvoja je zmogljivostim (prostorskim, regeneracijskim in nevtralizacijskim) okolja in naravnim virom (količini, kakovosti) trajno prilagojena prostorska razmestitev in s tem okoljskih pritiskov naselij, infrastrukture in pokrajinske rabe. Bolj uravnotežena, enakomernejša razporeditev okoljskih pritiskov in njihovo zmanjšanje glede na zmogljivosti okolja in prostora je temeljni okoljevarstveni cilj. Sistematično spremljanje in vrednotenje prostorsko pomembnih okoljskih problemov, okoljskih pritiskov in razvrščanje okoljskih problemov glede vplivov na bivalno okolje, rabo naravnih virov in funkcioniranje ekosistemov so temelji za zasnovo reševanja prostorsko relevantnih okoljskih problemov.

Nakazana inačica trajnostnega razvoja je brez dvoma temeljnega pomena za spodbujanje pestrega, kakovostnega in polnega življenja v vsakem kraju in v vsaki regiji. Slovenija ima ugodne prostorske razvojne možnosti za ustvarjanje take prostorske strukture, ki omogoča smotrno prostorsko razporeditev poselitvenih območij (stanovanj), delovnih mest in infrastrukture, in sicer v takem prostorskem vzorcu, ki bo kar v največji možni meri varoval odprti prostor. Prostorski razvoj usmerjan v razvojna območja, ki tvorijo privlačne urbane skupnosti različnih velikosti, in ki so ustrezno prostorsko razmeščene zagotavljajo zadosti 
prostora $\mathrm{v}$ vseh regijah za kakršne koli nadaljnje potrebe in razvoj, in to ob dejstvu, da ostaja večji del prostora odprt prostor. Slovenija želi ohranjati odprti prostor kot integralni del pokrajine.

Inačica trajnostnega razvoja daje Sloveniji dovolj možnosti za to, da nobena njena pokrajina, kraj, in naselje ni navadna, nezanimiva. Vsaka lahko s svojimi lastnimi potenciali, $\mathrm{v}$ medsebojni povezanosti in soodvisnosti $\mathrm{z}$ drugimi prispeva $\mathrm{k}$ temeljnim razvojnim pogojem, saj lahko številne raznolike in raznovrstne pokrajine razvijajo svojo polno moč skozi različne prostorske oblike, funkcije in strukture, ki pa se morajo razvijati v prostorski vzajemni soodvisnosti, s povezovanjem in dopolnjevanjem. Ravno te omenjene prostorske značilnosti dajejo veliko možnosti, da so različne oblike, funkcije in strukture v določenih prostorskih razmerjih, da so skupaj, druga ob drugi v urbani in podeželski pokrajini, in sicer z možnostjo sobivanja različnosti, in ne nazadnje tudi nasprotij.

\section{Literatura in viri}

Blaut, J., 1961. Space and Process, Professional Geography, Vol. 13, str. 1-7.

Chadwick, G., 1971. A Systems View of Planning. Pergamon, Oxford.

Christensen, K. S., 1985. Coping with Unceratinty in Planning. Journal of the American Planning Association, Vol. 51, No, 1, str. 63-73.

Černe, A., 1999. Prostorska identiteta - koncept različnosti. Anthropos, Časopis za psihologijo in filozofijo ter za sodelovanje humanističnih ved, letnik 31, štev. 4-6, str. 296-300, 4 cit. lit.

Černe, A., 1999. Nemoč ali kriza stroke? Razvojne možnosti Slovenije. 80 letnica oddelka za geografijo, dela 14, str. 63-75.

Černe, A., 1999. Questions of Regional Development in Slovenia (Vprašanja regionalnega razvoja Slovenije). Razvojne možnosti Slovenije, Bodočnost mest, 80. letnica Oddelka za geografijo, Dela 14, Oddelek za geografijo, Filozofska fakulteta, Univerza v Ljubljani, Ljubljana, str. 137-150.

Černe, A., Gulič, P., 1999. Prostorska politika države, Urbani izziv, letnik 10, št. 1, str. 5363.

Černe, A., 2001. Analiza prostorskih razvojnih možnosti. 2001, Raziskovalna naloga, nosilec raziskovalne naloge, Urad R Slovenije za prostorsko planiranje, Ministrstvo za okolje in prostor, str. 87, Ljubljana.

Černe, A., 2002. Preveritev skladnosti pripravljalnega besedila utemeljitve Strategije prostorskega razvoja Slovenije z besedilom Strategije prostorskega razvoja Slovenije. 2002, Projektna naloga, nosilec projektne naloge, Urad R Slovenije za prostorsko planiranje, Ministrstvo za okolje in prostor, str. 64, Ljubljana.

Černe, A., Kušar, S., 2002. Analiza stanja in teženj prostorskega razvoja v Republiki Sloveniji. Raziskovalna naloga, Oddelek za geografijo, Znanstveni inštitut Filozofske fakultete, Filozofska fakulteta, Urad R Slovenije za prostorsko planiranje, Ministrstvo za okolje in prostor, str. 105, Ljubljana.

Denmark Towards the Year 2018, 1992. The Spatial Structuring of Denmark in the Future Europe. Ministry of Environment, Copenhagen. 
ESDP, 1997. European Spatial development Perspective. Noordwijk, 09-10.06.1997, CEMAT, Cyprus, 16-17.10.1997.

Faludi, A., 1996. Rationality, Critical Rationalism and Planning Doctrine. Explorations in Planning Theory, Ed. S. J. Mandelbaum, 1. Mazza, R. W. Burchell, Center for Urban Policy Research, Rutgers, New Jersey. Str. 65-82.

Finland 2017, 1995. The Spatial Structure and Land Use. Ministry of Environment, Land Use Department, Helsinky.

Haggett, P., 1990. The Geographer's Art. Basic Blackwell, Oxford.

Hall, P., 1992. Urban and Regional Planning, Peter Hall, Routledge, London.

Hartschorne, R., 1939. The Nature of Geography: A critical survey of current thought in the light of the past, Association of American Geographers, Lancaster.

Hendler, S., 1990. Professional Codes as Bridges Between Planning and Ethics: A Case Study. Plan Canada, Vol. 30, No. 2, str. 22-29.

Lynch, K., 1981. A Theory of Good City Form. MIT Press, Cambridge.

Perry, R.B., 1948. The Thought and Character of William James, New York.

Rittel, H. W. J., Webber, M. M., 1973. Dilemmas in a General Theory of Planning. Policy Sciences, Vol. 4, str. 155-169.

The Europe 2000, 1991. Outlook of the Development of Community's Territory. DG XVI, Brussels.

Ule, A., 1992. Sodobne teorije znanosti. Znanstveno in publicistično središče, Ljubljana.

Vision and Strategies Around the Baltic Sea 2010 (1994) Towards a Framework for Spatial Development in the Baltic Sea Region. Group of Focal Points, The Baltic Institute, Karlskrona.

Volker, M. W., 2002. Biopolis. Patric Geddes and the City of Life. The MIT Press, Cambridge.

Webber, M. M., 1983. The Myth of Rationality: Development Planning Reconsidered. Environment and Planning B: Planning and Design 10, str. 89-99.

White Paper on Growth, Competitiveness and Employment, 1993b. The Challenges and Ways Forward into $21^{\text {st }}$ Century, Commission, COM, 39, 700, Brussels.

\section{PROFESSIONAL ANALYSIS IN SPATIAL PLANNING}

\section{Summary}

Spatial analysis is part of integration process of plan document elaboration and follows logic of description, evaluation, proposal, implementation and monitoring. From this aspect analysis can contribute towards spatial planning in different possible ways. First, a clear picture of the facts, current conditions, circumstances and trends helps to determine questions, objectives and priorities among them. Second, a good analysis of current and emerging regional conditions can contribute to the search of good solutions for development problems. Third, a good analytical material helps explaining and implementing spatial policies, concepts and strategies. From this aspects analysis contributes to accomplishment 
of the three basic aims of spatial planning: it is basic element for setting spatial policies, concepts and strategies, gives basic information to inhabitants, land owners, investors, planners and helps in performing spatial policies, strategies, plans, programmes and projects. Analysis in planning are generally devoted to:

- $\quad$ understand current circumstances and emerging conditions within planning decisions;

- determine priorities of open questions and their solutions;

- formulate general principles for further development.

This three main elements are related to the:

- fact component, which describes existing and projected conditions indicating the relative spatial problems or degree of object attainment and factors causing spatial problems;

- $\quad$ values component, which states goals, concerns or issues and priorities among them;

- policies component, which describes spatial planning principles to guide planning, spatial problem solving and setting priorities among issues and policies.

According to this the spatial plan should have three components: policies, goals and facts. Spatial planning policies are principles, based on objectives, goals and conditions, that suggest likely directions for spatial planning solutions. Spatial planning objectives and goals represent in one way spatial problems to be alleviated, aspiration to be achieved, or needs to be meet. And the fact component describes the spatial and other conditions pertaining to the spatial problems, aspirations and needs; causal factors relevant to spatial conditions; and factors that affect actions or their effectiveness.

Although we discuss spatial analysis before goal-setting, the planner usually caries out these tasks concurrently. Analysis of spatial conditions and causes reveals and elaborates on problems and otherwise feeds information in goal-setting, but at the some time the determination of community concerns, values and priorities helps to determine which facts and problems are relevant. Without clear goals, spatial problem identification is no more than a statement of existing spatial conditions, without any sense of why these conditions constitute a spatial problem. Goal-setting involves namely identifying present and future spatial problems, determining aspirations in the form of goals and objectives, and identifying strategic issues and priorities among them. We must be aware that in spatial plan or spatial planning policy formulation, we must accept that:

- $\quad$ any spatial plan or spatial planning policy is or should be concerned to resolve a number of spatial problems and issues;

- $\quad$ spatial problems and issues are inter-related to some degree.

Planning practice has traditionally assumed that both the objective and goals of spatial planning and the means of achieving them are known and accepted, i.e. the change being sought and the methods of bringing the change about are certain. In spatial planning reality, this kind of situation is much more complex. That is why we are facing with "problems of organised spatial complexity" characterised by interconnectivity, complexity, uncertainty, ambiguity, conflict and societal constraints. 
One of the major problems in spatial analysis is the question of determining the scope and focus of the analysis. What is the object of the analysis: spatial development? But how to determine spatial development: as possibility open to all of country's, region's or place's inhabitants to enjoy material and spiritual prosperity; or as spatial changes in the form of continuous development of individuals individuals or small groups and their culture? Attention should be devoted to facts about current spatial conditions, development trends and likely future conditions. If the facts about current spatial conditions are related to all human activities, than the analysis should be devoted to spatial extensions and impacts of these activities in physical space as a life space at different spatial level. If spatial conditions of life space have been growing worse, it would be very unusual to call the results of spatial development as "development", even if the GDP per capita doubled.

Within the spatial planning context these questions refer to the questions of quality of spatial development, which has a number of dimensions that can be expressed in varying degrees: vitality, sense, fit, access, control, efficiency and justice. Quality spatial development can be determined as a process where spatial structure becoming more complex, more richly connected, more competent and therefore "open space": accessible, diverse, adaptable, decentralised and tolerant to experiment.

In strategic spatial planning this track is referred to as scanning the external and internal spatial conditions to identify so called key development factors and trends and determine how external and internal forces and processes will likely influence future spatial development. Future economic, spatial and social conditions are represented through forecasting and scenario-building. Forecasting applies particularly to factors and conditions that are more or less foreseeable and can be estimated with different projection techniques. On the other hand, scenario-building is a more exploratory representation of alternative futures that could, or in a normative sense perhaps even should occur. Spatial analysis of past, present and emerging conditions are usually published in separate reports, as separate volumes of spatial plan, or integrated with the spatial planning policy and their principles, objectives and goals in a single document.

Within these framework the spatial analysis of the spatial conditions were elaborated and determined the list of spatial features as an exceptionally negative phenomena for further spatial development. Among these phenomena are most obvious:

- $\quad$ stagnation in the natural population growth, aging of the population, and a subsequent decrease in the share of the active population;

- depopulation of border and less developing areas;

- $\quad$ strongly self-serving and uncontrolled spatial development activities;

- unbalanced road and rail transport and a disregard for the modernization of railways and public transport;

- economic regression in old industrial areas;

- $\quad$ structurally and technologically undeveloped agriculture;

- inadequate system of farmland protection, particularly within infrastructurally well equipped and easily accessible development areas of towns;

- $\quad$ speculation in building land due to the absence of a land policy and an undeveloped real estate market; 
- $\quad$ absence of active, spatially balanced housing policy;

- deficient and absolute infrastructure in settlements, contributing to water, soil and air pollution, as well as to a higher cost of public utilities;

- $\quad$ unregulated waste and mineral resources management;

- $\quad$ highly endangered cultural landscape within the impact areas of big towns;

- forestation of the agricultural landscape due to the abandonment of farming;

- $\quad$ surface and underground water pollution, and a significant threat of flooding in some areas;

- unrecognised interests and pressures for utilizing the potential of the sea, sea-coast, and wider coastal belt;

- $\quad$ building construction without permits;

- $\quad$ extensive local pressure, as well as increased environmental and spatial pressures.

Because there are many explanations for these spatial problems also because there are unlimited possible range of methods which can be used to determine these problems, there are of course also very different solutions. Depending on the explanation chosen, the solution for spatial problems differs. The variety is infinite if we consider all aspects of spatial problem for, by the definition "all aspects" of the spatial problem are infinite and variety in the spatial problem must be matched by variety in the solver.

According to this findings the spatial conditions were evaluated for the determination of spatial development possibilities within the context of development scenarios, concepts, models, potentials and spatial development strategies from the international aspect of spatial development, economy, society, general spatial development, settlement system, infrastructure, landscape, regional development, environmental aspects of spatial development and from sectoral aspects (agriculture, forestry, water management, energy, mining). The general estimation for the spatial development alternative was elaborated for settlement structure, infrastructure, landscape, regional development and environmental aspects of spatial development. The spatial development possibilities indicate that Slovenia has development opportunities within:

- integration into the European space under equal terms,

- $\quad$ polycentric urban system and regional spatial development;

- $\quad$ vital and well-managed cities and towns;

- harmonized development of wider urban areas,

- integrated and harmonized development of transport and settlement networks and the construction of public infrastructure facilities;

- $\quad$ vitality and attractiveness of rural areas;

- $\quad$ enhancing the recognizability of valuable natural and cultural landscape characteristics;

- $\quad$ spatial development in areas with special potential and problems.

Within this estimation four spatial development visions as spatial development alternatives for Slovenia were determined:

- $\quad$ spontaneous spatial development;

- $\quad$ alternative intensive development, 
- intensive protection alternative

- $\quad$ alternative sustainable development.

These development alternatives resulted in the elaboration of Spatial Development Strategy of Slovenia (SDSS), which determines these spatial development objectives:

- rational and effective spatial development;

- polycentric development of the network of cities towns and other settlements;

- $\quad$ increased competitiveness of Slovenian towns in Europe;

- high-quality development and attractiveness of cities, towns and other settlements;

- harmonious development of areas with common spatial development characteristics;

- complementarity of rural and urban areas functions;

- $\quad$ integration of infrastructure corridors with the European infrastructure systems;

- $\quad$ prudent use of natural resources;

- $\quad$ spatial development harmonized with spatial limitations;

- cultural diversity as the foundation of the national spatial identity;

- nature conservation;

- environmental protection. 